\title{
Regional economic impacts of natural hazards - the case of the 2005 Alpine flood event in Tyrol (Austria)
}

\author{
C. Pfurtscheller \\ Institute for Interdisciplinary Mountain Research (IGF), Austrian Academy of Sciences, Innsbruck, Austria \\ Correspondence to: C. Pfurtscheller (clemens.pfurtscheller@oeaw.ac.at) \\ Received: 13 December 2012 - Published in Nat. Hazards Earth Syst. Sci. Discuss.: - \\ Revised: 20 November 2013 - Accepted: 17 December 2013 - Published: 25 February 2014
}

\begin{abstract}
Natural hazards have substantial impacts on economies on all scales. While the measurement of direct effects seems manageable, less is known about the dimensions of economic effects, especially on local and regional scales. The lack of standardized terminology, empirical data and methods currently hampers profound decision support. In our study of the 2005 flood event in the Federal State of Tyrol (Austria), which triggered about 264 million Euros in direct losses, we surveyed companies from all sectors of the economy to identify the drivers of economic effects. The main aim of the study was to assess the regional economic impacts on the gross regional product by the 2005 floods without macro-economic modelling techniques using bottom-up data. Using basic quantitative and qualitative methods, we established and analysed a data pool of questionnaire and interview results as well as direct loss data. Based on this empirical evidence, we estimated the decline in gross regional product in the study area at NUTS-3 level. We observed that disrupted traffic networks, for instance, had very negative effects on the regional economy. In addition, we identified economic winners of severe hazard impacts and estimated the amount of increasing economic flows (economic stimuli), based on compensation payments. Finally, the net effect can be estimated balancing the negative and positive effects of the flood event. The methods and results of this study can help to improve ex post loss estimations, and with it, ex ante methods for the cost efficiency of risk reduction measures, e.g. cost-benefit analysis. However, much effort is needed to improve the data basis on economic effects measured as a change in economic flows.
\end{abstract}

\section{Introduction}

The economics of natural disasters usually cover the aggregated effects on a national scale (Cavallo and Noy, 2009). Estimating the costs and economic effects of natural hazards is a necessary part of economic risk assessment to provide a sound basis for disaster reduction policies (Meyer et al., 2013). Due to the absence of comprehensive regionalised approaches and methods, and to missing regional data on economic activities, the gross regional product (GRP) in Europe, for instance, is only available at NUTS-3 level; the impacts of natural disasters and their channels on economic systems are not understood so far, even on a local scale (Przyluski and Hallegatte, 2011). Until now, economic effects of hazards in the Alps have neither been measured nor comprehensively analysed, except for high-impact events at the macro level using top-down approaches, which is carried out for instance for the 2002 floods in Austria. This event caused approx. EUR 2.3 billion in direct losses, inducing only about 180 million Euros in indirect losses and disruption of production (Kletzan et al., 2004) calculated by an input-output based macroeconomic model for the Austrian economy (Kratena and Zakarias, 2001). This is equivalent to approx. $0.1 \%$ of Austria's gross domestic product (GDP) in 2002.

Indirect effects and business interruption - which are both reflected in GRP - can be substantial at all levels of the economy and higher than the direct effects, at least for very high impact events with more than USD 200 billion in direct losses (Hallegatte, 2008). Missing data and methods at the meso and local levels hamper profound decision support for comprehensive risk management strategies and cost-efficiency analyses of mitigation measures in alpine 
environments (Pfurtscheller et al., 2011). Analysing the regional economic effects leads to the key issue of identifying and evaluating the drivers of these adverse effects at the company level and the resilience to system effects in the local and regional economy.

At the local level and from an ex ante perspective, costbenefit analyses for mitigation projects are carried out in nearly all countries of the Alpine arc (Pfurtscheller et al., 2011). However, indirect effects are rarely assessed in such frameworks, primarily due to missing empirical evidence and suitable bottom-up methods. Alpine hazards, e.g. rockfalls, landslides, debris flows and torrent processes, are mainly local processes with only marginal impact on the economy as a whole. As such processes often occur in parallel as multihazards during heavy-rainfall events, as happened during the 2005 floods in western Austria (Pfurtscheller and Thieken, 2013), the question arises if the adverse effects in their entirety are the sum of every single effect or if the partial impacts amplify the overall effect. Definitions and methodology regarding (regional) economic or indirect effects are not consistent, at least for levels lower than the macro economy (Przyluski and Hallegatte, 2011). Generally, input-output analyses can be applied for an assessment (e.g. Lin et al., 2012), but regional input-output tables for Austria are not available and must be regionalized using strong assumptions. Hence, validated and sound methodologies, assessments and case studies for local and regional scales are rare using validated bottom-up approaches, which can be applied for e.g. cost-benefit analyses and urgent policy decisions. To assess all possible regional economic effects by natural hazards, high efforts regarding data and methods are needed. Anyway, such data are mostly not available.

The main issues addressed in this study are the regional economic effects of the catastrophic floods in summer 2005 in the Federal State of Tyrol (Austria) using a bottom-up approach. We focus on the effects of the 2005 event on GRP, since this is the main indicator of economic development in a certain region. Since business interruption and indirect effects overlap to a certain degree (and are represented in GRP), both phenomena are included in the study. Also, on this scale of assessment it is not of prime importance if a company is directly affected or not. Different methodological steps are used to estimate the economic impacts. In particular, we analyse adverse effects on businesses (e.g. duration of the effects, effects on different economic branches) using survey results based on a questionnaire sent out to 4200 companies in regions affected by the 2005 floods, as well as the net effects on gross regional product, combining economic losses by estimating revenue decline and stimuli using compensation payments by public authorities. A macroeconomic study of the 2005 floods is used to compare the results (Sinabell et al., 2009). We also assess tourism impacts separately, since approx. $16 \%$ of the federal state GRP comes directly from tourism revenues. Finally, expert interviews are carried out to validate the quantitative results.
The study is organized as follows: the paper starts with a systemisation of economic effects (including indirect economic losses and business interruption) and provides some background information on other (regional) economic effects, examining different temporal (short- vs. long-term) and spatial (macro-, meso- vs. micro-economic) system boundaries. Methods to assess these effects were also introduced. The third section gives an overview of the case study, especially the floods of 2005 and the study region. Section 4 presents the used data and methods. Section 5 shows results of the different methodological steps (survey, interviews, calculation of tourism losses and net effects). Section 6 concludes and discusses uncertainties and assumptions as well as key benefits of the methods used and the results. We also point out issues for future research and provide some recommendations for public risk and disaster management.

\section{Estimating economic effects and indirect losses from natural hazards}

\subsection{Systemising the economic effects}

Much conceptual and recapitulatory work has been done to systematize the effects of natural hazards. Most studies focus on growth issues because of the availability of aggregated data and methods (cf. Benson and Clay, 2004; Cavallo and Noy, 2009). The disaster impacts on the economy in a given area refer to market (e.g. income) and non-market effects (NRC, 1999). A sound categorisation of the costs (or losses) of natural hazards has been given by Meyer et al. (2013). They distinguish between direct costs, business interruption, indirect effects, intangible effects and risk mitigation costs. Direct losses are losses due to the direct affection or destruction of houses and infrastructure and other physical assets. Business interruptions are again triggered by the physical affection of companies (e.g. machinery, car fleet, buildings) and result in limited or stopped production. Indirect effects are those losses, which were induced by direct losses or business interruption. Hence, a breakdown of forward and backward linkages is transmitted through the economic system (e.g. Cochrane, 2004). Such effects occur with a time lag and can be observed inside and/or outside of the affected area. Indirect effects as well as business interruption overlap to a certain degree, and hence a stringent concept is hard to apply (Meyer et al., 2013; Hallegatte and Przyluski, 2010, 2011). Costs for mitigation are those costs which were needed for risk reduction. In essence, these costs are spent on technical and non-technical mitigation. An overview of risk mitigation costs occurring in four different Alpine regions is given by Pfurtscheller and Thieken (2013), analysing these costs ex post using public budgets. Although the distinction of the costs of natural hazards by Meyer et al. (2013) is well reasoned, a variety of definitions of indirect and business 
interruption effects had been developed earlier (as presented by cf. Przyluski and Hallegatte, 2011).

Following the model of the economic cycle, economic effects of natural hazards affect every part of it through different channels. Indirect losses as well as business interruption are reflected in GDP/GRP as a decline in economic flows. Other economic impacts resulting from natural hazards, e.g. declining consumption through lost household income, subsequent interactions and declining taxes also affect GDP. These effects are mostly hard to measure (Cochrane, 2004) and not often considered (Cavallo and Noy, 2009). To sum up, the full economic costs of natural hazards are mostly not assessable due to the manifold channels and impacts on different economic dimensions.

Measured across the economy as a whole, catastrophic events also cause stimuli or positive economic flows through reconstruction and rebuilding of affected or destroyed public and private assets (Kletzan et al., 2004; Hallegatte, 2008; Sinabell and Streicher, 2009). Small-scale disasters in particular can have positive effects on the economy (Loayza et al., 2009), predominantly from repair and reconstruction, replacement of furniture or machinery, and from clean-up activities. Two different economic flow values can thus be observed in the aftermath of a catastrophic event: indirect losses and business interruption as declining economic activities and positive consequences or economic stimuli. So far, it has not been possible to distinguish or analyse these contrasting flow values because GDP/GRP includes both. Hence, what are reflected in economic aggregates are the total effects (the net effects) of a hazard on a certain scale, measured in flow values.

Rose (2004) and Cochrane (2004) provide basic principles for evaluating indirect effects of natural hazards and for understanding them better. Messner et al. (2007) as well as Merz et al. (2010) have compiled a state-of-the-art loss assessment and present rules and conventions for evaluating flood losses for different damage categories. As the main principle in the assessment of indirect effects, the determination of spatial and temporal boundaries is of prime importance and the purpose of a study (Messner et al., 2007; Merz et al., 2011; Pfurtscheller et al., 2011). Essentially, indirect effects cancel each other out through substitution of goods and services, if the analysed period is long enough and the region large enough (NRC, 1999).

\subsection{Methods to assess indirect economic effects and business interruption}

The extent of existing data largely influences the methods available for assessing indirect effects and business interruptions. Generally, natural hazards can have effects on different economic parameters at different levels of aggregation. To measure these effects, macro-scale and top-down methods have mostly been used (Cochrane, 2004; Cavallo and Noy, 2009). Meyer et al. (2013) present a large overview of studies. They separate methods for assessing business interruptions (sector-specific models, event analyses and a fixed share of direct losses) and indirect effects (event analysis, econometric approaches, input-output modelling, CGE models, intermediate and idealized models). The methods can also be subdivided into ex ante and ex post assessments, whereof the former analyses the possible effects in advance of an adverse impact and the latter assesses the effects after an event occurred. In this paper, only a short review of available studies is given.

To assess business interruption, sector-specific models mostly by applying loss of value added are presented by e.g. MURL (2000) and SLF (2000). In the aftermath of the avalanche winter of 1999, Nöthiger (2003) assessed the decline in touristic income on a local scale based on empirical data from a questionnaire and provided a statistical tool to estimate future indirect losses from avalanches. Chatterton et al. (2010) analyse the total economic costs of the 2007 floods in England based on regional studies and internal institutional surveys resulting in an estimated GBP 3.2 billion. They do not assess indirect economic effects, but increased costs of business (e.g. additional transport costs) and costs of disruption of provision. In this survey, it is also stated that 160 million pounds were claimed from insurance companies for business interruption and lost income. Effects on macroeconomic aggregates were not assessed. In Austria, costbenefit analyses for technical mitigation measures against the above-mentioned hazards is carried out assessing indirect losses and business interruption effects within the risk area, although these effects were mostly not analysed due to a missing stringent concept (BMLFUW, $2008 \mathrm{a}$ and b). Hence, loss of value added per affected employee is used. In these assessments outside effects are neglected. Fixed share of direct losses to assess business interruption is presented by the Department of Natural Resources and Mines (2002). They calculate indirect losses by estimating them as a percentage of the direct losses, without any empirical validation. They used $15 \%$ in the case of residential damages and $55 \%$ in the case of commercial damages.

Indirect economic effects are analysed by applying event analyses, econometric approaches, input-output modelling and CGE models. For the Alpine space, Kletzan et al. (2004) assessed the impacts on a national scale of the 2002 floods in Austria. They used a welfare approach and a disaggregated model, and calculated effects on consumption, investments, imports, exports, GDP and final demand. 180 million Euros in indirect losses were estimated. This is equal to approx. $0.1 \%$ of Austria's GDP in 2002. To estimate potential losses by heavy impact hazards ex ante, the HAZUS MH software was developed, which also includes a methodology to assess indirect losses for earthquakes and floods (Scawthorn et al., 2006a, b). The module is based primarily on inputoutput modelling using an algorithm that rebalances interindustry trade flows, which are varianced by changing supplies and demands due to the hazard impacts (FEMA, 2011). 
The module therefore considers supply shortages, declines in sales, and opportunity costs. Hallegatte et al. (2010) as well as Ranger et al. (2011) use the Adaptive Regional InputOutput (ARIO) model provided by Hallegatte (2008) to assess the economic effects of climate change. Rose and Liao (2005) focus on business resilience of water supply disruptions using a CGE model in the aftermath of a fictitious earthquake in the US to analyse the regional economic impacts for different economic sectors. To sum up, it is apparent that indirect effects and business interruption effects often overlap, and a stringent concept to measure these effects is hard to apply.

\section{Case study: 2005 floods in the Federal State of Tyrol (Austria)}

The event happened in August 2005 and caused about 592 million Euros in direct losses of private and public assets across four federal states and an estimated 264 million Euros in the Federal State of Tyrol (Sinabell and Streicher, 2009; Sinabell et al., 2009), although earlier estimates pinpoint 410 million Euros in Tyrol (Central Auditing Authority of the Federal State of Tyrol, 2006, 2007). $61 \%$ of these losses occurred in private households and companies, $18 \%$ in the transport network, $9 \%$ at hydraulic constructions and $5 \%$ in municipality infrastructures and $7 \%$ in other categories (telecommunications, water and energy supply, torrent and avalanche mitigation). As indicated by a macroeconomic analysis based on national input-output and interregional trade data, the 2005 event caused only a marginal decline in GDP for the national economy, but also a slightly positive effect (approx. $0.1 \%$ of GRP) in the Federal State of Tyrol (Sinabell et al., 2009). The reasons for this are the high investments and repair stimulus in the aftermath and the advantages of local producers. Based on this poor empirical evidence for local and regional impacts, we analysed the regional economic consequences of the 2005 event for the Federal State of Tyrol. Moreover, such macro-economic studies neither provide information on the impacts within the most affected areas, nor at the company level. Hence, a bottom-up analysis was carried out. 208 million Euros of the total direct losses of the 2005 event were compensated by the public risk transfer system (Central Auditing Authority of the Federal State of Tyrol, 2006, 2007). Based on data of the Austrian Disaster Fund provided by the Federal State of Tyrol, 190 businesses were directly affected during the 2005 flood event in the whole federal state, with a total direct loss of 64.8 million Euros (at 2006 values). The average direct loss of the companies was approx. 0.3 million Euros per municipality and 0.34 million Euros per company (median $90 \mathrm{k}$ Euros). However, these data do not include losses of state- or federalstate owned institutions (e.g. federal railways, electricity suppliers, avalanche and torrent control) or losses which were not reported to the disaster fund (for a short description of the disaster fund see Sect. 4.3.2).

The Paznaun valley in the NUTS-3 Tyrolean Oberland region was the worst hit area due to waters with the highest ever measured return periods (Federal State of Tyrol, 2006). The study area is equivalent to the NUTS-3 Tyrolean Oberland region, where we concentrated on the Paznaun valley (Fig. 1). This Alpine lateral valley has only one major road connection to the Inn valley and one road (closed in winter because of the risk of avalanches) over a pass to the western Federal State of Vorarlberg. We chose this heavily affected valley as the main study region because of our focus on the special situation of closed Alpine economies. Generally, the district of Landeck is characterized by structural imbalance, high unemployment and relatively low wages compared to the whole NUTS-2 region (Table 1). The economy is heavily dependent on winter tourism. The service sector provides approx. $70 \%$ of the jobs in the district of Landeck. The district generates a gross added value of EUR 2.3 billion. On average, one business unit in this area produces economic flows of approx. 0.5 million Euros. As a special characteristic of Alpine lateral valleys, the marginal permanent settlement area, which is about $4 \%$ in the Paznaun valley, restricts economic activities to the valley floor. Consequently, business units as well as structures and the population as a whole are prone to high flood and torrent risks.

The Paznaun valley includes the municipalities of Galtür, Ischgl, Kappl and See and, with approx. 260 million Euros, contributes over-proportionally to the gross added value compared with the district of Landeck and the NUTS-3 level. This is mainly due to earnings from high-intensity winter tourism. The municipality of Ischgl is among the top three winter destinations in Austria, with over one million overnight stays per year. Like the whole NUTS-3 region, the Paznaun valley is highly dependent on tourism revenues. The valley has high rates of commuters and tourist flows and therefore, in the case of road closures, makes local businesses vulnerable to indirect effects. Approximately 600 people commute every day to the valley and 700 out of it, not counting the commuters within the valley (source: Statistics Austria).

\section{Data and methods}

As no comparable studies on local and regional economic effects on mountain hazards were available, this paper examines the regional economic impacts of the 2005 flood event in the Federal State of Tyrol (Austria), while focussing on the effects in the NUTS-3 region Tyrolean Oberland. Effects outside the study areas were neglected. We are aware that we analysed an individual event, but case studies are a meaningful instrument for assessing the economic effects of adverse impacts at the meso and micro levels, since few comparable data and studies are available (Pfurtscheller et al., 


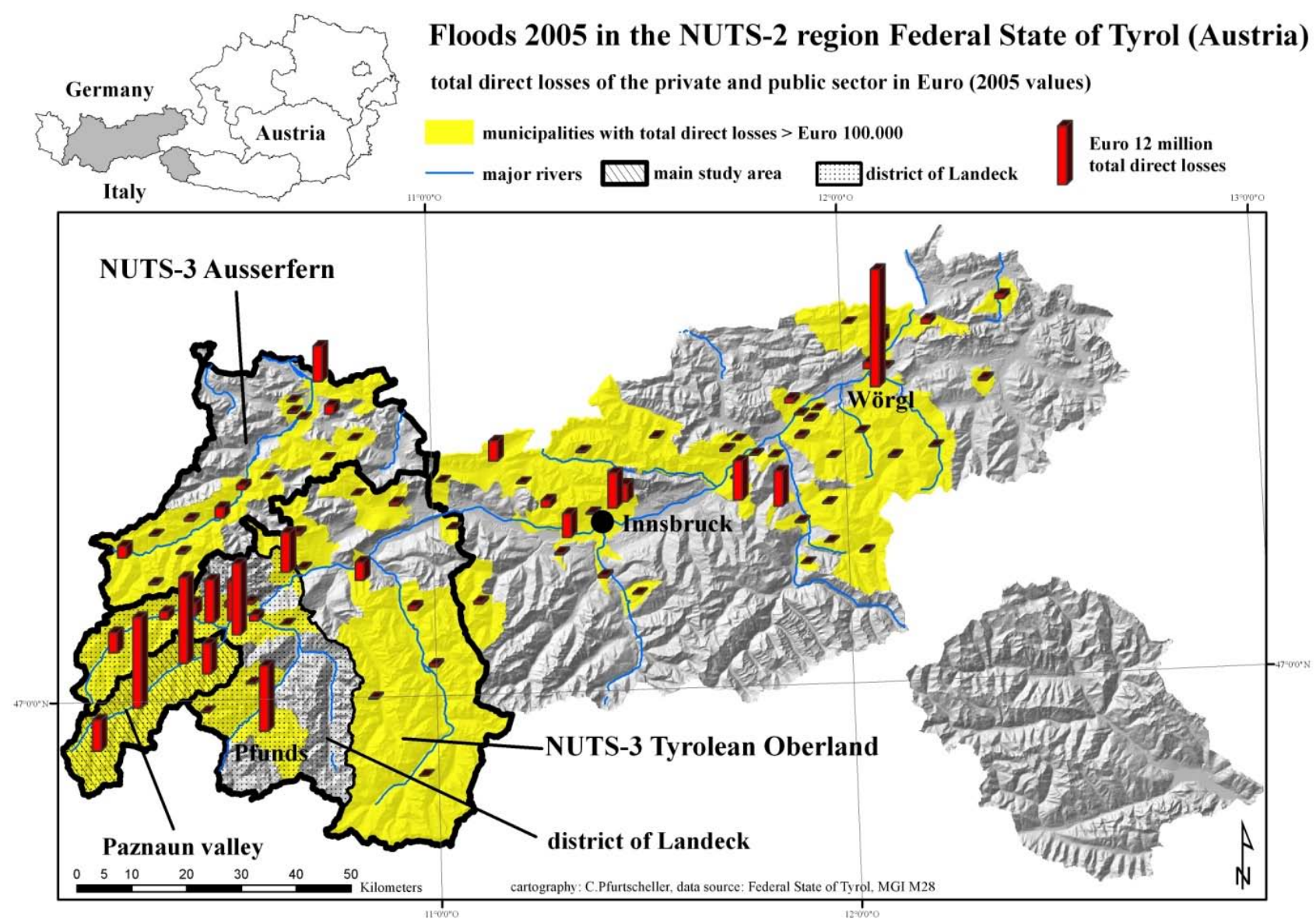

Fig. 1. Cartographical overview of recorded total direct losses $>100000$ Euros in the public (municipality and federal assets) and private sectors (households, businesses) at the municipal level, the assessed NUTS-3 regions, the main study area, and the most affected municipalities in the Federal State of Tyrol (Austria); Data source: Federal State of Tyrol (Austrian Disaster Fund / department for rural areas and agriculture, department for roads and traffic, department for municipal affairs).

Table 1. Main socio-economic facts of the study areas at different levels of aggregation; source: Statistics Austria, Federal State of Tyrol.

\begin{tabular}{lrrrr}
\hline & $\begin{array}{r}\text { Paznaun } \\
\text { valley }\end{array}$ & $\begin{array}{r}\text { District } \\
\text { of Landeck }\end{array}$ & $\begin{array}{r}\text { NUTS-3 region } \\
\text { Tyrolean Oberland }\end{array}$ & $\begin{array}{r}\text { NUTS-2 region } \\
\text { Federal State of } \\
\text { Tyrol }\end{array}$ \\
\hline Population (2001) & 6307 & 42795 & 100451 & 673504 \\
Rate of unemployment (2005) & n.a. & $10.5 \%$ & n.a. & $5.8 \%$ \\
Number of businesses (2001) & 562 & 2837 & 5922 & 39792 \\
Employees (2001) & 2342 & 16344 & 34988 & 295390 \\
Median wages per month in Euros (2010) & n.a. & 1992 & n.a. & 2079 \\
Nominal GRP in million Euros (2003) & n.a. & 1210 & 2187 & 19244 \\
Nominal gross added value in million Euros (2003) & $260^{*}$ & 1139 & 2344 & 18126 \\
\hline
\end{tabular}

* estimate

2011), besides a macro-economic assessment by Sinabell et al. (2009). In particular, we assess the total/net effects expressed in GRP. This includes an estimation of the decline in business revenues (transferred into GRP values) and of the economic stimuli based on compensation payments. This includes both business interruption and indirect effects, since the overlapping of these effects is apparent on such scales. Moreover, special focus is placed on tourism impacts.

Within this study, we used a threefold strategy to examine the regional economic effects of the 2005 flood event. First, a postal questionnaire was carried out focussing on the effects on single companies. Second, expert interviews 
were conducted to identify the qualitative dimension of the regional economic effects. And finally, available statistical data in combination with achieved data and results of the first methodological step were used to calculate tourism losses and the total regional economic effects expressed in GRP. The focus in this paper is on methods and calculation techniques to estimate the adverse impacts quickly, but also the economic stimuli. The different methodological steps and the combination of these methods and data aim to identify possible contradictions of the qualitative and quantitative results, but also to analyse different stakeholder views.

\subsection{Postal questionnaire}

To collect primary data on indirect effects and business interruption occurring at single businesses, a standardized postal questionnaire, combined with an online alternative, was conducted. Several pre-tests with companies and the chamber of commerce were carried out in 2011. Based on 9000 businesses in the broader study area and in the NUTS-3 Ausserfern region (see Fig. 1), we asked 4200 randomly distributed companies. To keep the focus on the most affected area, we surveyed all businesses in the Paznaun valley. The survey contained details on the following issues: (a) general business characteristics: location, sector, employees, annual revenue, locations of the inputs and outputs; (b) direct losses: amount, categories; (c) indirect losses: amount, categories, triggers; (d) financial effects on the business and duration of the effects; (e) investment: categories, amount; and finally, (f) positive effects and beneficiaries of the 2005 flood event (see Appendix A). Finally, the rate of return was only seven per cent $(n=282)$. This is very critical, especially for estimating short-term economic losses. A comparable survey carried out in 2009 resulted in a response rate of nearly $14 \%$ (Thieken et al., 2012). One main reason for this low response rate is the long time interval since the event happened and the low topicality at the time of the survey. This was also stated in the pre-tests and especially by the chamber of commerce (S. Garbislander, personal communication, 2011).

Nearly $40 \%$ of the 282 companies surveyed in the study region belong to the tourism sector and related businesses, followed by $23 \%$ small traders and $15 \%$ trade. $70 \%$ of the companies are small businesses with fewer than ten employees. Only $4 \%$ of the sample are companies with a staff of more than 250 . The low annual revenues per company provide further evidence of this fragmented, remote and tourismaffected economy. $68 \%$ of the companies return annual revenues of less than one million Euros. Regarding the intermediate inputs of the surveyed businesses, $53 \%$ source them locally and regionally. Only $32 \%$ get their inputs from the rest of Austria and from abroad. Not surprisingly, $88 \%$ of the companies distribute their goods and services in the region.

\subsection{Expert interviews}

Guided expert interviews were carried out in the Paznaun valley with mayors, the tourism association, a hotel, a bank, mountain railways and construction companies on the following topics: type and trigger of indirect losses, duration of the effects, investments subsequent to the flood event and positive effects/beneficiaries. The main reason for these additional interviews was to identify possible contradictions and analogies with the postal survey. We asked open questions to obtain free replies without restricting the interviewees to categories and schemes.

\subsection{Assessing the economic impacts using available statistical data and survey results}

Available statistical data were used and analysed (e.g. overnight stays, GRP) for the assessment of impacts on the tourism sector and on economic growth. Next, the decline, but also the stimuli of the 2005 event are estimated and transferred into GRP values leading to the net effects of the 2005 flood.

\subsubsection{Tourism impacts}

Since tourism is of great economic importance for the Paznaun valley, we analysed these impacts separately. First, the development of overnight stays in the Paznaun valley is analysed using overnight stays at different levels of aggregation provided by Statistics Austria, and second, the decline in revenues in the Paznaun valley is estimated using the approach by Nöthiger (2003), shortly presented in English in Nöthiger and Elsasser (2004). Nöthiger's method (2003) relies primarily on extensive questionnaires in the aftermath of the 1999 avalanche winter in Switzerland. He surveyed cable car companies, restaurants, hotels, private accommodations and hostels, retail businesses and other tourism-related companies for the indirect consequences in the avalanche-affected regions in Switzerland. Moreover, he interviewed daily and non-daily visitors in the municipalities of Davos and Elm. Based on this empirical evidence he assessed the decline in income from tourism after the 1999 winter and provided a statistical tool to calculate the effects ex ante in a certain region linking changing touristic frequencies with their daily expenses. The tool relies on regressions combining change of overnight stays for a specific time period and disrupted traffic network, as well as death toll. This study aims to analyse short-term local impacts, while impacts outside of the study region are neglected (e.g. substitution of touristic regions). It is argued by Nöthiger (2003) that the tool could also be used for other hazards occurring in the Alpine space and in the summer season. To calculate the decline in income from tourism, data on the number of overnight stays, average daily expenditure of tourists, duration of the impacts on the region, share of day visitors and the share of private rooms 
are needed and were provided by Statistics Austria and the Paznaun tourism association.

\subsubsection{Estimating the net effects of the 2005 event}

To analyse the total adverse economic impacts of the 2005 floods (the net effects) at the regional level, we calculate the lost GRP per employee based on revenue data and the main results of the postal survey. The short-term positive impacts on the regional economy were also assessed. An exact quantification of the total economic effects of the 2005 flood event in Tyrol - and of local/regional events in general - is not possible now, but a sufficient estimate of these effects can be achieved if some assumptions are made.

The simple and quick approach for extrapolating decreasing revenues to the NUTS-3 Tyrolean Oberland study region is based on available statistical data and the empirical findings of the postal survey, using average values. A similar approach for directly affected structures - without any empirical validation - was used by the Department of Natural Resources and Mines (2002) to calculate business interruption losses by estimating them as a percentage of the direct losses. They used $15 \%$ in the case of residential damages and $55 \%$ in the case of commercial damages.

To calculate the economic stimuli, we used payments for the total direct losses on a single object basis based on in situ observations to estimate the economic stimuli. These data stem from estimates of the direct losses of private households and companies and were provided by the Federal State of Tyrol, department for rural areas and agriculture, based on the Austrian Disaster Fund Act as a basis for disaster relief. Austria has a national risk transfer system, which relies primarily on a public funding scheme based on the Disaster Fund Act of $1966^{1}$ with several amendments in recent decades (Gruber, 2008). Private insurance companies rarely cover floods and similar processes (Holub and Fuchs, 2009). In general, the fund compensates direct losses of private (households and companies) and administrative bodies (municipalities, federal states). The federal states are responsible for the administration of the damage cases and receive payments from the fund. Due to the catastrophic impacts of the 2002 and 2005 floods, Austria established additional national acts to sustain the national risk transfer system and to guarantee the financing of the Austrian Disaster Fund via extraordinary national payments to the fund (flood victim compensation and rebuilding acts of 2002 and $2005^{2}$ ). Finally, we related a simple GRP analysis from 2001 to 2008 - also combined with survey results - to the analysis of the total net effects of the 2005 event.

\footnotetext{
${ }^{1}$ Katastrophenfondsgesetz 1966 (Disaster Fund Act), BGBl. 207/1966.

${ }^{2}$ Hochwasseropferentschädigungs- und Wiederaufbau-Gesetz (HWG) 2002 and 2005, BGBl I 155/2002 and BGB1. I Nr. $112 / 2005$.
}

\section{Results}

This section presents the results in the same order as the different data and methods are described. It starts with the findings of the postal survey. Then, the results of the expert interviews are described in a table. Finally, the economic impacts using available statistical data and survey results are specified. This includes the calculation of the decline in touristic revenues, estimates of short-term economic losses and economic stimuli as well as an analysis of the observed GRP from 2001 to 2008. Finally, the total economic effects on GRP values are estimated and compared with the results of the top-down macro-economic study by Sinabell et al. (2009).

\subsection{Postal questionnaire}

Here we summarize the basic results using descriptive statistics. We focussed on direct and indirect losses, their triggers and amounts, measured in percentage of annual revenues, the proportions of direct losses, indirect losses and investments, the financial impacts and their duration. We asked the companies for the extent of the variable relative in $\%$ based on the annual revenue, since the pre-tests had shown that the companies do not share exact figures for sensitive data like direct or indirect losses or profits. Hence, a quantification of direct losses, indirect effects, business interruption and investments could be made (and served as a guiding value for estimating the short-term economic losses). Finally, we identified positive effects and beneficiaries of the 2005 flood event. Please note that the basic variable statistics can be found as appendices.

\subsubsection{Direct losses, indirect losses, and investments}

In our sample, 76 companies were directly affected by the flood, with a mean value of nearly $30 \%$ of their annual revenue (median $10 \%$ ). In the main, structures, outside facilities and access roads were struck, but also machinery and infrastructure/provision. Over 100 companies stated that the indirect effects were mainly triggered by disrupted transport networks. At company level, broken lifelines, but also the absence of employees engaged in emergency operations (e.g. as voluntary members), road closures and the decline in demand caused indirect effects (Fig. 2).

145 companies of the sample suffered from indirect economic effects and business interruption (51\%). 80 of them offered quantitative data (Fig. 3). Mean indirect effects including business interruption amounted to $11.4 \%$ of annual revenues (median 10\%). Business interruption effects (businesses without any direct losses) were stated at about 11.8 $\%$ of annual revenues (median 5\%). 82 companies made investments $(29 \%)$ which were directly caused by the floods. In the mean, 54 companies stated their investments at $22.6 \%$ of the annual revenue (median $7.5 \%$ ). 


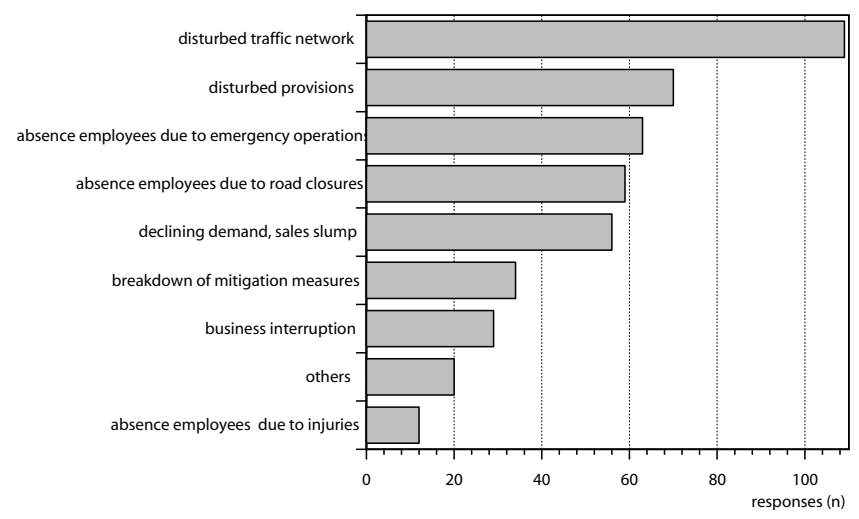

Fig. 2. Companies' estimates of the triggers of indirect effects, multiple responses, $n=145$.

The lion's share was invested in repairing structures. We also asked for repairs that were not investments in the strict sense but which will result in increased economic flows. Less than a third of the surveyed businesses improved their insurance cover and built/renewed mitigation measures. Even fewer companies used the adverse impact as an opportunity to implement risk management tools or to adapt production or storage. This implies that at company level only a marginal learning (or experience) effect has taken place after the 2005 flood.

\subsubsection{Financial impacts on the businesses}

Generally, $68 \%$ of the companies did not experience any positive or negative financial impacts from the flood event. $25 \%$ experienced losses and $7 \%$ recorded positive impacts. Examining the different economic branches, the tourism and leisure industry $(33.8 \%)$, industry and production $(28.6 \%)$, and retail (27\%, Fig. 4) observed the highest negative financial impacts expressed in decreasing revenues.

Not surprisingly, the construction industry $(50 \%)$, the transport and logistics sector (25\%) and the industry and production sector $(14.3 \%)$ increased their revenues while also suffering from the event in part. However, more companies from the construction and transport sector returned increased rather than decreased values and thus are the net "winners" of such events.

\subsubsection{Duration of the effects and changing revenues}

In the economic analysis of such events, the time horizon of the impacts is important for estimating the total effects (Messner et al., 2007). Hence, we asked the companies for the duration of the impacts, first, on their own business and second, on the whole region. Nearly $75 \%$ of the surveyed businesses were only affected during the flood event and in the following months until the end of the year. The impacts on the region lasted longer, as stated by the companies, although - in the short term - the company impacts exceeded

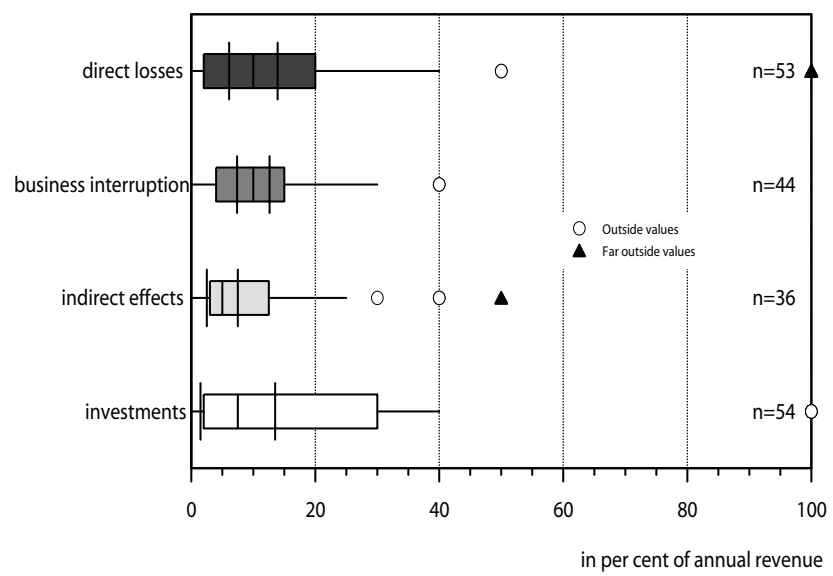

Fig. 3. Boxplot of direct losses, business interruption, indirect losses and investments in \% of annual revenue based on companies' estimates. Please note that all given values $>100 \%$ have been changed to 100 (seven cases).

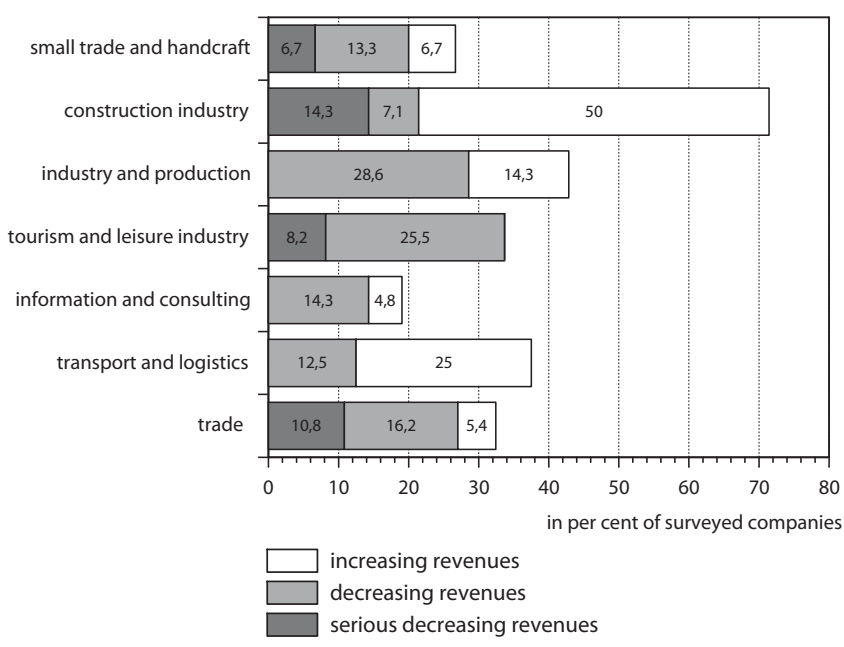

Fig. 4. Companies' estimates of sectoral financial impacts in terms of changing revenues, $n=81$.

those for the whole region. Surprisingly, the effects on the winter season, even though the region is primarily dependent on tourism, were marginal. This may be because visible damage was covered by snow from the beginning of November. The impacts on the 2006 summer season were higher because of the visibility of affected assets and reconstruction works (Fig. 5).

To link information on economic impacts in the regional and company estimates, we asked for the annual change in revenues from 2003 to 2009. Again, this is sensitive information and the businesses are not providing exact values for the change in revenues. Caution must be applied to judge the significance of these results given the low rate of responses. Based on a $5 \%$ classification, we identified trajectories for different sectors (Fig. 6). In the mean and in the assessed 


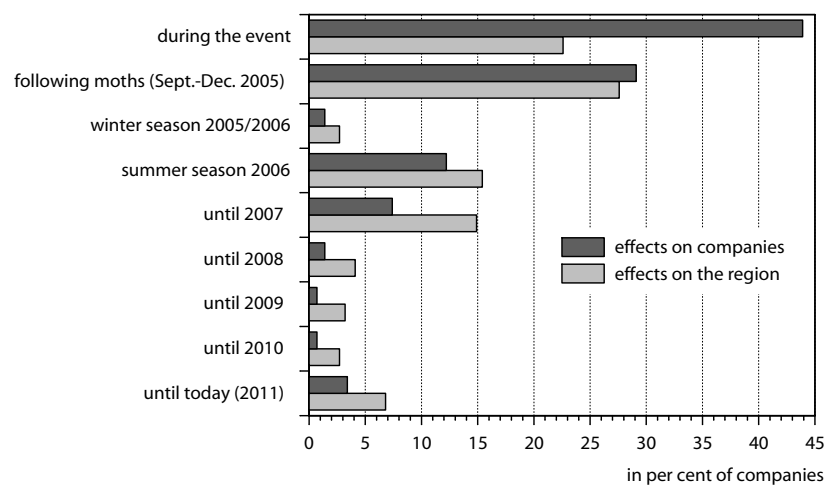

Fig. 5. Companies' estimates of the duration of the economic impacts on companies and on the region; $n=148$ for companies, $n=221$ for the region.

periods, the growth of company revenues is stable at 1 to $5 \%$. In the year of the event, revenues stagnated at the previous year's level.

However, the trajectories differ greatly by economic sector. Evening out of revenues can be observed for retail, tourism and leisure, small traders and the construction industry. A strong increase - starting from a low level - took place in the transport and logistics sector in 2005 and 2006, with a higher growth of more than $10 \%$. This must be interpreted with caution, because only two companies offered data. Revenues grew strongly in the construction industry in 2006. As an explanation it was to be expected that cleanup, immediate and short-term necessary earth movement and road (re)building would occur after the event (before the start of the winter season). The 2006 growth in the construction industry can be explained by the fact that the main reconstruction and rebuilding of affected structures, but also the installation of new mitigation measures, had to be done after snowmelt, i.e. from early April/June until October/November. The other sectors show a relatively homogenous development, apart from the information and consulting sector, but also banks and insurance companies. It can be assumed that these sectors are not affected by the floods, rather by the general economic conditions, which could not separate within this study.

\subsubsection{Positive effects and beneficiaries}

Generally, flood events like the one of 2005 also have positive effects. The main triggers of the positive economic effects (e.g. rising revenues) are found in the repair, rebuilding/reconstruction of assets, in clean-up, the higher demand for producer goods and other inputs, the installation of new mitigation measures and a growing demand for consumer goods (Fig. 7).

We also asked open questions about positive effects and the beneficiaries of the flood event. Surprisingly, $40 \%$ of the respondents see installing new mitigation measures, and to a lesser extent, upgrades or improvements to the public infrastructure, as well as the increased awareness of natural processes, as stimuli for the local and regional economy. The emerging solidarity in the affected population was mentioned as a positive effect.

Only $9 \%$ of the surveyed companies stated that the 2005 event did not have any positive consequences. Regarding the beneficiaries of the event, about $70 \%$ of the respondents stated that the construction industry and related trades (earth moving, haulage and transport) were economic "winners" of the 2005 event (Fig. 8).

\subsection{Expert interviews}

This section provides a summary of the guided qualitative interviews in the most affected region (Paznaun valley) in table form. In total, we carried out ten interviews: four with mayors, three with representatives from the tourism sector (hotel, tourism association, railway company), and three with people from other companies (construction industry, earth movement, bank). Table 2 summarizes the most important statements of the guided interviews. Overall, the statements of the guided interviews matched the results of the postal survey and gave some new insights into the effects of the 2005 event on the municipalities.

\subsection{Assessing the economic impacts using available statistical data and survey results}

This section estimates the economic impacts by using available statistical data starting with impacts on tourism. Then the negative and positive effects triggered by the 2005 floods are presented and the total economic net effects of the 2005 flood event in GRP values are summed up.

\subsubsection{Tourism impacts}

Generally, overnight stays in the assessed regions grew between 2001 and 2009, as shown in Fig. 9. Compared with the development of overnight stays in the whole of the federal state (dotted line), the assessed regions show a more dynamic development because of their great dependence on tourism and related service industries. It is also apparent from this figure that in the year of the event and in the two consecutive years, overnight stays stagnated at different levels of aggregation, especially in the Paznaun valley. Overnight stays fell by 36400 or nearly $61.5 \%$ from September 2004 to September 2005. We assume that the fall in overnight stays was mainly triggered by the 2005 flood event. Because the assessed regions are mainly winter destinations (approx. 70 to $90 \%$ of total overnight stays, depending on the municipality), the 2005 flood had no severe impacts on the annual tourist flows. The effect of the flood event could not easily be isolated from the general economic and touristic development in the assessed regions, but we assume that the impact 
Table 2. Final summary table of the guided interviews.

\begin{tabular}{|c|c|c|c|}
\hline & municipalities & tourism & companies \\
\hline $\begin{array}{l}\text { direct } \\
\text { losses }\end{array}$ & $\begin{array}{l}\text { high loss of structures } \\
\text { and infrastructure } \\
\text { of tourists and directly hit structures }\end{array}$ & $\begin{array}{l}\text { abrupt end of the } 2005 \text { summer season due } \\
\text { to departure } \\
\text { the location }\end{array}$ & $\begin{array}{l}\text { different degree impacts, } \\
\text { depending on }\end{array}$ \\
\hline $\begin{array}{l}\text { indirect } \\
\text { losses }\end{array}$ & $\begin{array}{l}\text { disrupted transport } \\
\text { lines and provision }\end{array}$ & $\begin{array}{l}\text { decline in income through cancellations and early } \\
\text { departures, a minus of } 50000 \text { overnight } \\
\text { stays in the Paznaun valley compared with } 2004\end{array}$ & $\begin{array}{l}\text { disrupted transport lines and provision, } \\
\text { absence of employees }\end{array}$ \\
\hline $\begin{array}{l}\text { duration of } \\
\text { the impacts }\end{array}$ & $\begin{array}{l}\text { short- to long-term } \\
\text { effects up to the present }\end{array}$ & $\begin{array}{l}\text { severe impact on } 2005 \text { and } 2006 \text { summer } \\
\text { seasons }\end{array}$ & $\begin{array}{l}\text { different duration of the impacts, } \\
\text { depending on the location; } \\
\text { more short-term impacts until end of } 2006\end{array}$ \\
\hline investments & $\begin{array}{l}\text { reconstruction and rebuilding, } \\
\text { new mitigation measures, improvement of } \\
\text { public risk and disaster management } \\
\text { (danger zone planning, disaster management) }\end{array}$ & $\begin{array}{l}\text { most of the company premises were } \\
\text { repaired, some investments in touristic } \\
\text { infrastructure } \\
\text { (hiking paths) }\end{array}$ & $\begin{array}{l}\text { depending on the degree of impact, } \\
\text { upgrades were carried out (cars and trucks, } \\
\text { machinery, } \\
\text { mitigation measures) }\end{array}$ \\
\hline $\begin{array}{l}\text { positive } \\
\text { effects }\end{array}$ & $\begin{array}{l}\text { strengthened solidarity in affected } \\
\text { areas, high generosity, } \\
\text { improvements in public infrastructure }\end{array}$ & $\begin{array}{l}\text { no positive effects, } \\
\text { no negative impacts on destination image }\end{array}$ & $\begin{array}{l}\text { improvements in public infrastructure, } \\
\text { special credit regulations } \\
(0 \% \text { interest rates for five years })\end{array}$ \\
\hline beneficiaries & $\begin{array}{l}\text { construction and reconstruction } \\
\text { sector and related trades } \\
\text { (transport, earth movement) }\end{array}$ & $\begin{array}{l}\text { no beneficiaries in } \\
\text { the tourism sector } \\
\text { (transport, earth movement) }\end{array}$ & $\begin{array}{l}\text { construction and reconstruction } \\
\text { sector and related trades }\end{array}$ \\
\hline
\end{tabular}

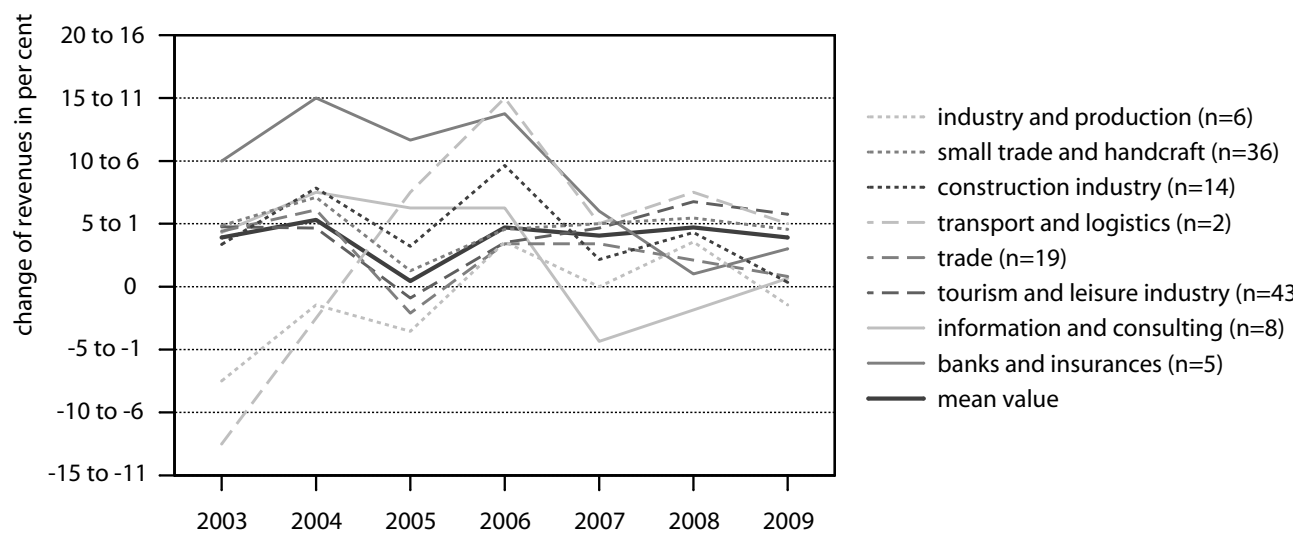

Fig. 6. Mean annual change of revenues from 2003 to 2009 based on companies' estimates, $n=133$ incl. multiple entries.

of the 2005 floods affected mainly the overnight stays in the summer season.

On the basis of Nöthiger (2003), we calculated a shortterm decline (including 2006) in tourist expenditure of about 5.24 million Euros (Table 3, 2.8 million Euros in GRP values). For this method, the following data must be known and were fully provided by the Paznaun tourism association (D. Walser, personal communication, 2011): number of overnight stays (140000 in the month of the event and 50000 in the consecutive month), average daily expenditure of tourists (96 Euros), duration of the impacts on the region (20 days), share of day visitors $(20 \%)$ and the share of private rooms $(25 \%)$.

Overall, the results of Nöthiger's approach fit very well with the calculations and estimates of the tourism association. They calculated the decline in tourist expenditure (rev- enues) in September 2005 as amounting to ca. 3.5 million Euros (D. Walser, personal communication, 2011). The decline calculated with the Nöthiger method is 3.3 million Euros in the same month (Table 3 ). This means a decline in GRP of approximately 1.8 to 1.9 million Euros. Concluding the section on tourism impacts, the 2005 event severely affected the Paznaun valley, especially in the 2005 to 2007 summer seasons. Only marginal effects were observed in the broader study region. In total, a decline in tourism income of approx. 5.2 million Euros was calculated. Not included in this figure are long-term or multiplier effects and the missing compulsory contributions to the tourism association (approximately 1 million Euros, D. Walser, personal communication, 2011). The long-term impacts on the tourism sector were minor, because the infrastructure and accommodation facilities were reconstructed very rapidly in the following years. 
Table 3. Results of the calculation of the decline in touristic income in the Paznaun valley as a result of the 2005 flood event, based on Nöthiger (2003), in 2011 Euro values; input data provided by the Paznaun tourism association (D. Walser, personal communication, 2011).

\begin{tabular}{|c|c|c|c|c|c|c|}
\hline expenditures & accommodation & board & retail & $\begin{array}{r}\text { cable } \\
\text { cars }\end{array}$ & $\begin{array}{r}\text { other } \\
\text { expenditure** }\end{array}$ & $\begin{array}{r}\text { total } \\
\text { in Euros }\end{array}$ \\
\hline August 2005 & 0 & -473600 & -219300 & -87500 & -135400 & -915800 \\
\hline in $\%$ & 0 & -12 & -10 & -13 & -9 & $-5 \%$ \\
\hline September 2005 & -1788200 & -730300 & -375900 & -124700 & -270400 & -3289500 \\
\hline in $\%$ & -60 & -54 & -52 & -54 & -54 & $-57 \%$ \\
\hline long-term* & -585600 & -214700 & -114900 & -36600 & -82600 & -1034400 \\
\hline in 2005 & -1788200 & -1203900 & -595200 & -212200 & -405800 & -4205300 \\
\hline total in Euros & -2373800 & -1418600 & -710100 & -248800 & -488400 & -5239700 \\
\hline
\end{tabular}

* August 2006, ${ }^{* *}$ transport, entry fees, sports courses.

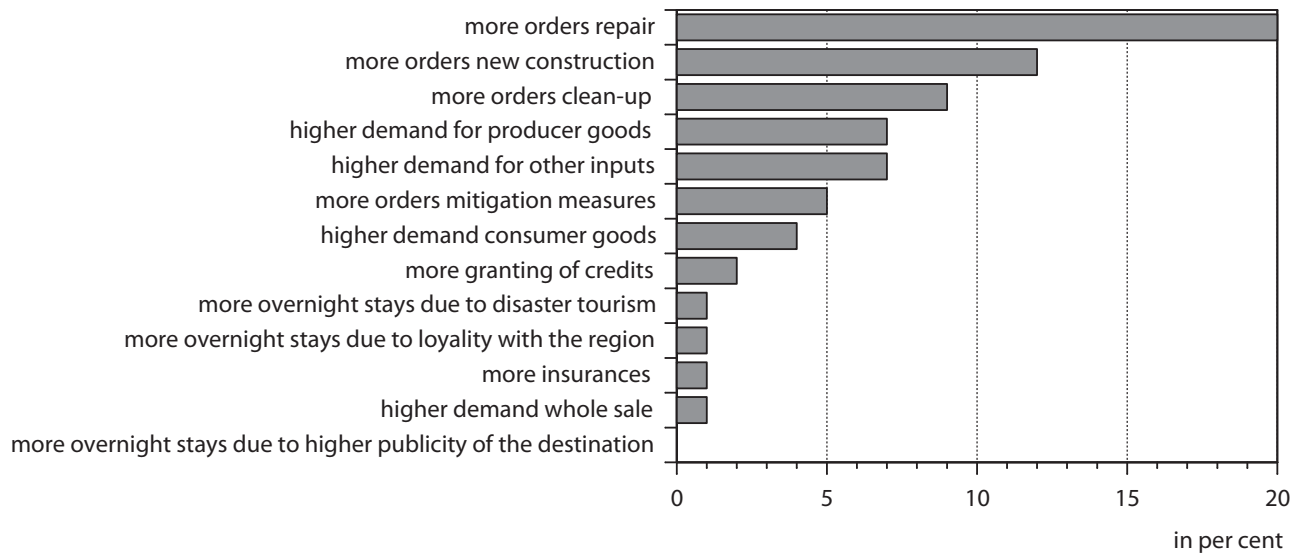

Fig. 7. Companies' estimates of triggers of rising revenues, multiple responses, $n=70$.

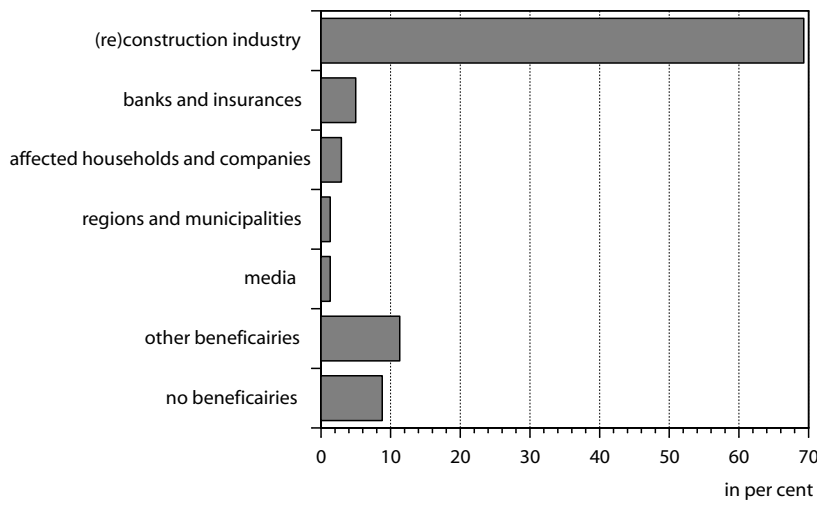

Fig. 8. Companies' estimates of economic sectors that benefited from the 2005 flood event, multiple responses, $n=238$.

\subsubsection{Estimates of short-term economic losses}

In our survey, we identified the median of indirect losses (including business interruption) as $10 \%$ of annual turnover (mean $11.4 \%$ ). Moreover, $51 \%$ of the sample was affected by the 2005 flood event. In general, $75 \%$ of the surveyed businesses were only affected by the flood event itself and

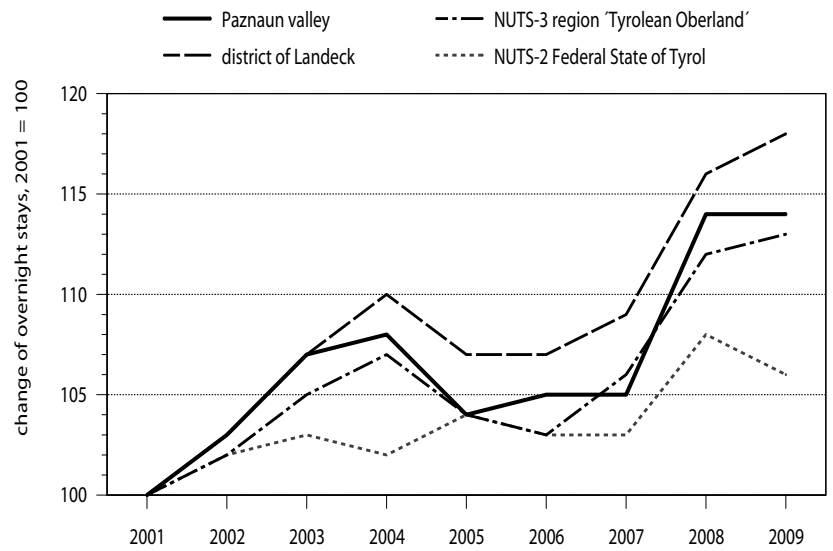

Fig. 9. Overnight stays in the study regions at different levels of aggregation for the touristic year (01/11 to 31/10) from 2001 to 2009; source: Statistics Austria.

in the following months until the end of the year. For the calculation, we assumed the severe impacts in terms of lost turnover for the businesses to have lasted 5 to 10 days. Table 4 sums up the estimates of the short-term effects. Based on the number of companies and employees in the three 
Table 4. Estimates of short-term economic losses of the 2005 floods in NUTS-3 region Tyrolean Oberland; source: Statistics Austria and authors' calculations.

\begin{tabular}{|c|c|c|c|c|c|c|}
\hline & $\begin{array}{r}\text { NUTS-3 } \\
\text { region } \\
\text { Tyrolean } \\
\text { Oberland }\end{array}$ & $\begin{array}{r}\text { affected } \\
\text { (51\% of } \\
\text { total) }\end{array}$ & $\begin{array}{r}\text { primary } \\
\text { sector }\end{array}$ & $\begin{array}{r}\text { secondary } \\
\text { sector }^{2}\end{array}$ & $\begin{array}{r}\text { tertiary } \\
\text { sector }\end{array}$ & total \\
\hline number of companies & 2837 & 1447 & $3 \%$ & $24 \%$ & $73 \%$ & $100 \%$ \\
\hline number of employees & 35000 & 17850 & 535.5 & 4284 & 13030.5 & 17850 \\
\hline average GRP/employee/working day ${ }^{1}$ in Euros & - & - & 150 (estimate) & 332.5 & 359.8 & - \\
\hline short-term indirect losses in 10 days in Euros & - & - & 803250 & 14244300 & 46883739 & 61931289 \\
\hline
\end{tabular}

${ }^{1}$ The average GRP/employee/working day is calculated by using Table A3 (see Appendix), ${ }^{2}$ without energy supply.

different sectors, we used average GRP values per working day to extrapolate the economic impacts. Only $51 \%$ of the GRP is used since the 2005 flood only affected about half of all businesses. Calculated by this method, the short-term decline in revenues in the first 10 days after the event was about 62 million Euros.

Comparing these results with Sinabell et al. (2009), who calculated the total negative impacts on GRP from 2005 to 2020, they put the impacts at $0.4 \%$ of the GRP of 2005 . This means approx. 77 million Euros. Hence, an underestimation of the effects is calculated due to the short-term analysis (10 days).

\subsubsection{Estimates of economic stimuli}

As presented in the results of the postal survey, natural hazard events, like the 2005 flood in western Austria, also create economic "winners". Our focus in this paper is on methods and calculation techniques to estimate the adverse impacts quickly, but also the economic stimuli. One possible way to estimate positive impacts measured in growing revenues or GRP is based on national compensation payments. In Austria, the Disaster Fund, based on specific regulations, counterbalances direct losses of private households and businesses. Fortunately, the fund also estimates the total direct losses of assets. For the calculation of economic stimuli, it can be assumed that all assets were repaired or rebuilt after a catastrophic event. Again, backward or forward economic linkages are neglected. Moreover, the needed goods and services are assumed to be fully produced inland. The economic profits from rebuilding and repairing public assets at diverse administrative levels, e.g. transportation infrastructures, must be analysed separately. We did not analyse induced effects due to the very vague data basis. Nor did we include insurance payments. For this estimate, the Federal State of Tyrol provided the following data: single-object compensation payments and total direct loss estimates of the Austrian Disaster Fund for the 2005 floods (2100 cases in total) and detailed estimates of direct losses of municipal, district and federal state assets. For the private sector, $59 \%$ of the losses were compensated on average by the Disaster Fund. We as- sume that $100 \%$ of the public losses were compensated (or fully repaired/renewed), since this assumption is also applied by Sinabell et al. (2009). The total payments were computed using these compensation rates (Table 5).

From the rough calculations in Table 5 we can say that a minimum of 165 million Euros can be attributed as increasing revenues to the 2005 flood event. This estimate neglects additional investments and "upgrades" as well as improvements in productivity. Assuming that all direct damages were obviously repaired, which seems more realistic (in the case of $100 \%$ compensation of the private sector), the economic stimuli (as additional revenues) rise to approx. 208 million Euros. In the construction industry, one Euro revenue has an impact on GRP of 0.51 Euros using Table A3 (Appendix A). Therefore, the positive impacts of the 2005 event on the GRP can be estimated with about 84 to 106 million Euros. This means roughly a rise of 0.43 to $0.55 \%$ in the federal state GRP assuming that all goods and services for repair and rebuilding were purchased in the federal state. To compare, Sinabell et al. (2009) calculated approx. 125 million Euros stimuli to GRP for the federal state, analysing the total effects from 2005 to 2020 . These slightly higher effects could well be explained by the fact that direct losses occurred at state- or federal state-owned institutions (e.g. federal railways, electricity suppliers, avalanche and torrent control) or that losses that were not reported to the Disaster Fund are not included in the calculation of Table 5. The share of the NUTS-3 Tyrolean Oberland region can be calculated roughly by analogy to the share of total direct losses to the affected private households and companies (104 million Euros) in the NUTS-3 region (67 million Euros). This share of $64 \%$ can be combined with the effects in the federal state. All in all, the economic stimuli in the NUTS-3 region can be put at 54 to 68 million Euros rise in GRP.

\subsubsection{GRP analysis and total economic effects}

If one analyses the growth of the GRP from 2001 to 2008 at different levels of aggregation, the NUTS-3 Tyrolean Oberland region had a below average growth rate in 2005 of $3.6 \%$ compared with the federal state level (NUTS-2, $6.6 \%$ ) 
Table 5. Rough calculation of economic stimuli based on damage compensation in million Euros for the Federal State of Tyrol (2006 values); Data sources: Austrian Disaster Fund, Federal State of Tyrol, department for rural areas and agriculture and own calculations.

\begin{tabular}{lrrrrr}
\hline $\begin{array}{l}\text { in million Euros } \\
\text { (2006 values) }\end{array}$ & companies & $\begin{array}{r}\text { private } \\
\text { house- } \\
\text { holds }\end{array}$ & $\begin{array}{r}\text { municipal } \\
\text { assets }\end{array}$ & $\begin{array}{r}\text { federal } \\
\text { assets }\end{array}$ & $\begin{array}{r}\text { total direct } \\
\text { losses }{ }^{3} \text { total } \\
\text { compensation }\end{array}$ \\
\hline direct losses & 64.8 & 39.6 & 27.1 & 76.3 & 207.8 \\
average compensation rate in \% & $59^{1}$ & $59^{1}$ & $100^{2}$ & $100^{2}$ & - \\
total compensation & 38.2 & 23.4 & 27.1 & 76.3 & 165 \\
\hline${ }^{1}$ This rate is calculated by the Austrian Disaster Fund's estimates of the total direct loss, divided by the final payments, ${ }^{2}$ we \\
assume that all direct losses of public bodies were fully repaired and rebuilt, ${ }^{3}$ the total direct losses do not include losses which \\
occur at state- or federal state-owned institutions (e.g. federal railways, electricity suppliers, avalanche and torrent control or \\
losses that were not reported to the Disaster Fund).
\end{tabular}

(Fig. 10). In absolute values, this means approx. 90 million Euros for the study area. The sharp decline in growth for the region in 2005 stands against the general economic development of the total NUTS-2 level and especially the NUTS-3 level (for example, the Tyrolean Unterland). It is highly likely that this contrary development of the broader study area was triggered by the flood event. In the following year, the lower growth rate of the study area can be put at 60 million Euros. In 2007, the growth rate recovered to an average level and the other assessed regions show a lower growth rate. This conflicting development of the study region could be attributed to the strong repairing, rebuilding and upgrading of private and public assets.

In a next important step, the revenue information of the survey (Sect. 5.1.3) can be compared with the general economic tendencies of the region. Combining both flow values - the growth of the region and changing revenues provided by the questionnaire - we can conclude that the surveyed companies reported lower business growth (as changing revenues, hatched areas, Fig. 10) than the whole NUTS-3 Tyrolean Oberland region. However, it must be assumed that the respondents to the questionnaire were mainly companies directly or indirectly affected by the floods. The results are also distorted by businesses not being quite honest about benefitting from the event. Nevertheless, the Paznaun valley and the surrounding NUTS-3 region suffered more than the other regions.

Concluding, the total economic effects (the net effects: stimuli minus decline in GRP) in the assessed NUTS-3 Tyrolean Oberland region can be estimated at approximately minus 7.7 to plus 6.3 million Euros (Table 6). For the Federal State of Tyrol, a marginal positive effect of approximately 7 to 29 million Euros can be estimated. To judge these results, it is important to distinguish between short- and long-term effects. The decline in GRP of about 90 million Euros in 2005 (Fig. 10) coincides with the estimation of short-term decline in GRP, because multiplier effects or effects which last longer that the considered period (10 days) are not included in the calculation. It can be assumed that most of the reconstruction and repair stimuli were reflected in 2007 and the
Table 6. Overview of the total effects in GRP Euro million based on own calculations and Sinabell et al. (2009).

\begin{tabular}{lrr}
\hline & $\begin{array}{r}\text { NUTS-3 } \\
\text { region } \\
\text { Tyrolean } \\
\text { Oberland }\end{array}$ & $\begin{array}{r}\text { NUTS-2 } \\
\text { region }\end{array}$ \\
\hline $\begin{array}{l}\text { Federal State } \\
\text { of Tyrol }\end{array}$ \\
$\begin{array}{l}\text { negative impacts/decline } \\
\text { positive impacts/rise } \\
\text { in GRP in Euro millions } \\
\text { total effects }\end{array}$ & 61.9 & approx. 77* \\
\hline
\end{tabular}

* These values are read out of graphs provided by Sinabell et al. (2009). Therefore, the results must be interpreted with caution.

following years. Hence, the long-run slightly positive effects as indicated by this study and Sinabell et al. (2009) seem realistic, although the low growth of the analysed NUTS-3 Tyrolean Oberland region in 2006 cannot be explained well. However, a longer period needs to be considered, if the total net effects should be analysed.

\section{Conclusions and discussions}

What is needed within risk and disaster management strategies for natural hazard impacts at diverse levels are exercisable approaches and methods for assessing the indirect consequences of natural hazard events, with acceptable uncertainties and resources needed. Such a methodology should provide explicit pointers to the public and private sectors to improve decision making in compensating future losses and investing in technical and non-technical mitigation measures. Therefore, this paper examines the regional economic effects of the 2005 flood event in the Federal State of Tyrol (Austria), based on primary and secondary data. As mentioned in the literature review, these effects were mostly not assessed within the framework of event or risk analysis, although the results are highly relevant for future risk prevention strategies and urgent policy decisions. Macro-economic studies neither 


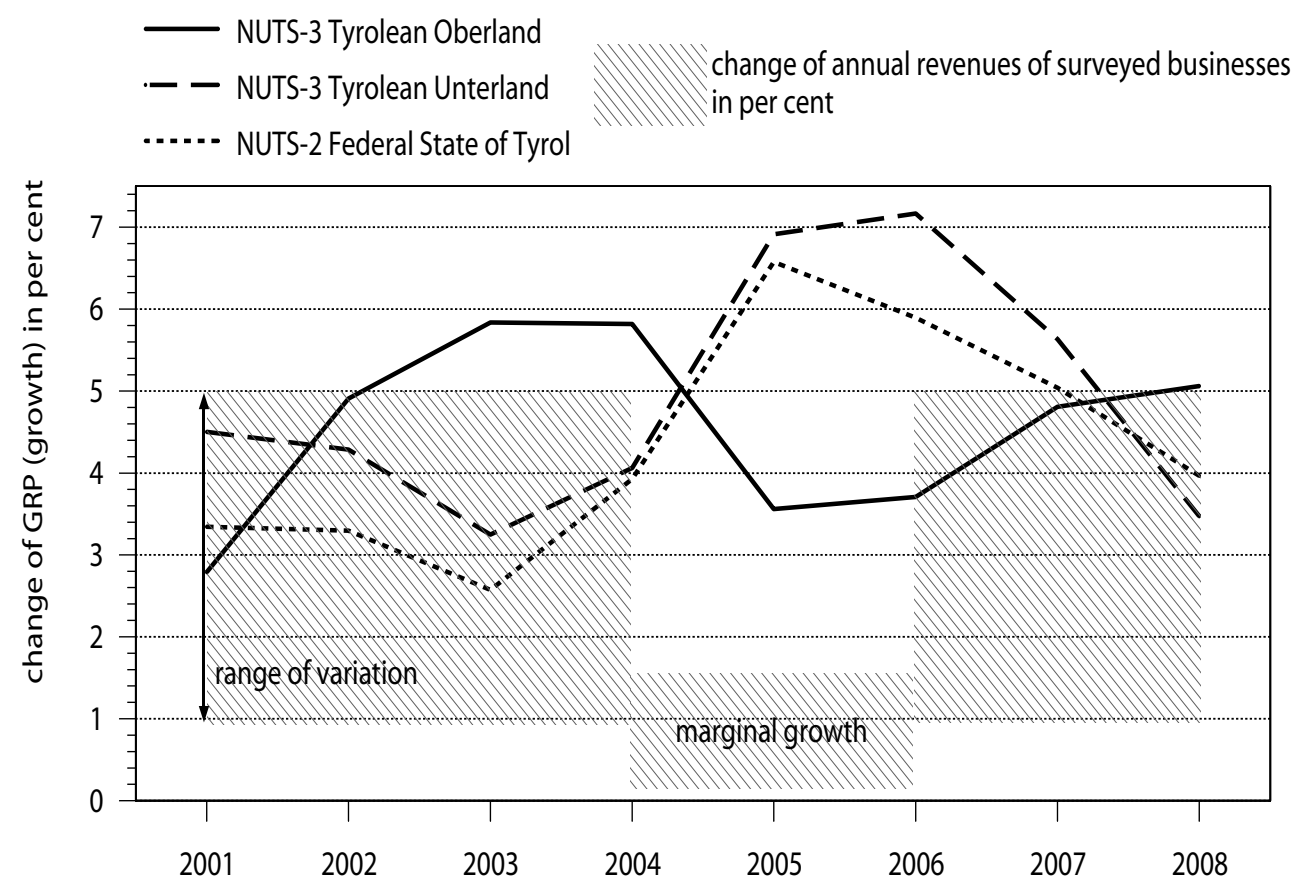

Fig. 10. Annual economic growth at NUTS-2/NUTS-3 level and change in annual revenues of surveyed businesses in $\%$ from 2001 to 2008 , $n=125$; source: Statistics Austria, questionnaire.

provide information on the impacts within the most affected areas at the local and regional levels, nor at the company level. Hence, a bottom-up analysis was carried out. We used basic quantitative and qualitative methods to draw conclusions about the overall economic effects of the 2005 flood in GRP values. This is done by estimating the economic losses using extrapolation of a fixed share of indirect losses (including business interruption) and estimating the economic stimuli to calculate the net effects on GRP. A fixed share of indirect losses is applied by the Department of Natural Resources and Mines (2002) without any empirical validation. Since we use results of the postal questionnaire on the decline in revenues, it seems to be a better basis for estimating the economic effects on GRP. Moreover, we use the duration of the effects, as stated by the companies, which will also improve the robustness in estimating the short-term adverse economic effects expressed in GDP.

Finally, the total effects in the NUTS-3 Tyrolean Oberland region can be put at about plus 6 million Euros, assuming that all destructed assets were fully repaired and rebuild, which seems realistic. At the federal state level, the impacts on GRP were slightly positive, which is also indicated by Sinabell et al. (2009). Disrupted transport networks were the main cause of the decline in business revenues. Companies which have been affected directly by damages to structure or machinery do suffer more from declining revenues than companies without any direct losses. The 2005 event also brought about economic winners due to the repair, reconstruction and upgrade of private and public assets. As a review of the guided expert interviews and the quantitative estimations shows, the results match.

Based on the empirical findings and available data, we presented a basic approach for assessing the short-term economic impacts measured in declining revenues. The approach relies primarily on the number of affected businesses, the duration of the effects, annual revenue and number of employees. The estimation of economic stimuli is based on compensation payments of the total direct losses. These approaches can be used in cost-benefit frameworks, but also to estimate the economic consequences quickly in case of past disasters to have a sound basis for policy-relevant decisions (e.g. special funding programmes for companies). The presented empirical approaches are simple, do not need sophisticated knowledge in macro-modelling techniques, and have been developed for application by public authorities and risk managers.

To judge the results and methods presented in this paper, we found that if different quantitative and qualitative methods and data are used, it is possible to set limits and roughly estimate the total economic effects without macro modelling top-down approaches. Uncertainties in the data and empirical results strongly affect the analysis of the regional economic effects of the 2005 flood event. The necessary data for the assessment of the effects are rarely available. E.g. insurance claims for business interruption losses as used by Chatterton et al. (2010) to assess the effects on businesses are not open to the public in Austria. Therefore, the postal survey as well as the expert interviews serve as a basis for estimating the 
regional effects to have a benchmark for flood processes in similarly developed regions in the European Alps. The data of the survey will be biased by multiple causes, e.g. it can be strongly assumed that more affected companies than nonaffected replied. As the analysis was carried out more than six years after the event, there was little interest in replying to the survey. Of course, the results have to be weighted with regard to this low response rate. The analysis of the net effects in particular tends to be vague. Nevertheless, the main aim of the paper is to estimate the dimension and not the exact quantification of the effects. In assessing regional economic effects, the considered period (short- vs. long-term) and the scale of assessment are of prime importance and therefore should be determined in advance of an assessment. This is closely connected to the distinction between business interruption and indirect effects, which is not possible and not necessary on a regional scale. From a local perspective, it makes absolute sense to analyse indirect effects and business interruption separately, as the effects of both on revenues might differ. The approach estimating the decline in GRP can well be applied, e.g. for a cost-benefit analysis. The approach calculating the economic stimuli is more appropriate for an estimation for the total/net effects. Finally, the analysis focused on a solitary event and does not use data of any other events or studies for validation. This probably distorts the results when analysing the effects of other natural hazard events using approaches of this study.

To assess the regional economic impacts of the 2005 flood event, strong assumptions have to be made. First, the methods focus on short-term adverse impacts on the regional economy, using revenue changes of the businesses. Mid- or long-term effects, as well as high-order or ripple effects, are neglected and can only be analysed by estimating the total net effects based on time series data, but unfortunately the economic trajectory without the adverse impacts is unknown. We focus on the measurable part of the total economic effects. Hence, the negative and positive economic impacts at micro and meso level are difficult to assess and cannot easily be demarcated from profits resulting from the event. Secondly, the approaches cannot identify the effects of economic connections with backward (suppliers) and forward (customers) linkages or effects outside the study region, including multiplier effects. But from a regional policy perspective, outside effects are not the focus of interest. Thirdly, we neglected a possible change in the economic structure, which can be triggered by the movement of companies and labour or resettlements of severely endangered areas.
One of the issues that emerge from the findings is that public institutions, especially in data sharing of public flood management, the Austrian Torrent and Avalanche Control, and Austrian Disaster Fund, should be intensified to have more information on direct and economic consequences of every single damaged object. Therefore, this needs minimum standards for data collection of the negative and positive economic effects arising at the affected businesses on different temporal scales. However, more research on this topic is needed to understand the linkages of stock and flow measurement with the effects of natural hazard events. Generally, the economic impacts of disasters are measured in direct losses. It would be desirable to combine these (stock) values with economic ones to get to know the total effects of the exogenous impacts on the economy. This is closely connected with the measurement of the economy as a whole, which is based on flow values. Disasters seem per se to be positive for GDP/GRP, given that the loss of buildings etc. is not included in GDP, but the reconstruction and repair. Therefore, flow values, like GDP/GRP, would reflect the net effects of a natural hazard event better than direct losses. More research is necessary here to improve the interaction between direct losses and their economic consequences. Another topic for future work is improving cost-benefit and cost-effectiveness frameworks by considering economic effects. Up to now in Austria such analyses have been carried out but without a closer look at economic effects (Pfurtscheller et al., 2011).

To verify the results presented in this paper, further case studies of similar catastrophic events should be carried out. Since for the calculation of economic losses an empirically grounded fixed share of economic effects is used, further analyses would improve this estimation. Finally, the trajectories of economic development without the flood event are unknown. Research should be undertaken to separate these effects, e.g. when analysing economic effects, regions without any impacts should be surveyed to compare the changing revenues of businesses and their impacts on economic aggregates. Finally, data at company level should be collected to improve the future basis for model development. 


\section{Appendix A}

Table A1. Overview of questionnaire topics and attributes.

\begin{tabular}{|c|c|c|c|c|c|c|c|}
\hline topic & question & attributes & & & & & \\
\hline \multirow{5}{*}{ 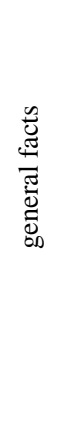 } & municipality & name, postal code & & & & & \\
\hline & \multirow[t]{2}{*}{ economic sector } & $\begin{array}{l}\text { trade and } \\
\text { industry }\end{array}$ & $\begin{array}{l}\text { (re)construction } \\
\text { industry }\end{array}$ & $\begin{array}{l}\text { industry and } \\
\text { production }\end{array}$ & $\begin{array}{l}\text { tourism and } \\
\text { leisure industry }\end{array}$ & $\begin{array}{l}\text { information } \\
\text { and consulting }\end{array}$ & $\begin{array}{l}\text { banks and } \\
\text { insurance com- } \\
\text { panies }\end{array}$ \\
\hline & & $\begin{array}{l}\text { transport and } \\
\text { logistics }\end{array}$ & trade & additional entry & & & \\
\hline & employees & 1 to 2 & 3 to 10 & 11 to 19 & 20 to 49 & 50 to 249 & $>250$ \\
\hline & $\begin{array}{l}\text { estimated annual } \\
\text { revenue in million } \\
\text { Euros }\end{array}$ & $\begin{array}{l}<0.1 \\
50 \text { to } 100 \text { Mio. }\end{array}$ & $\begin{array}{l}0.1 \text { to } 0.5 \text { Mio. } \\
>100\end{array}$ & 0.5 to 1 & 1 to 5 & 5 to 10 & 10 to 50 \\
\hline \multirow{3}{*}{ 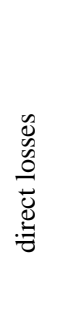 } & $\begin{array}{l}\text { directly affected } \\
\text { company }\end{array}$ & yes/no & & & \multirow{3}{*}{ machinery } & \multirow{3}{*}{ access road } & \multirow{3}{*}{$\begin{array}{l}\text { outside } \\
\text { facilities }\end{array}$} \\
\hline & & structures & inventory & $\begin{array}{l}\text { automobiles } \\
\text { and trucks }\end{array}$ & & & \\
\hline & $\begin{array}{l}\text { categories of direct } \\
\text { losses (multiple } \\
\text { responses) }\end{array}$ & $\begin{array}{l}\text { supply of water, } \\
\text { electricity and } \\
\text { gas (provision) }\end{array}$ & $\begin{array}{l}\text { long-term } \\
\text { damages } \\
\text { (e.g. mould) }\end{array}$ & $\begin{array}{l}\text { ground water } \\
\text { damage }\end{array}$ & & & \\
\hline \multirow{4}{*}{ 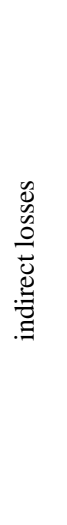 } & $\begin{array}{l}\text { indirectly affected } \\
\text { company (multiple } \\
\text { responses) }\end{array}$ & yes/no & & & & & \multirow{4}{*}{$\begin{array}{l}\text { disrupted } \\
\text { provisions }\end{array}$} \\
\hline & & $\begin{array}{l}\text { disrupted trans- } \\
\text { port networks }\end{array}$ & $\begin{array}{l}\text { absence of em- } \\
\text { ployees due to } \\
\text { road closures }\end{array}$ & $\begin{array}{l}\text { absence of em- } \\
\text { ployees due } \\
\text { to emergency }\end{array}$ & $\begin{array}{l}\text { absence of em- } \\
\text { ployees due to } \\
\text { injuries }\end{array}$ & $\begin{array}{l}\text { business } \\
\text { interruption }\end{array}$ & \\
\hline & $\begin{array}{l}\text { triggers of indirect } \\
\text { losses }\end{array}$ & $\begin{array}{l}\text { breakdown of } \\
\text { mitigation mea- } \\
\text { sures }\end{array}$ & $\begin{array}{l}\text { declining de- } \\
\text { mand, sales } \\
\text { dump }\end{array}$ & $\begin{array}{l}\text { operations } \\
\text { others }\end{array}$ & & & \\
\hline & $\begin{array}{l}\text { financial impacts on } \\
\text { the business }\end{array}$ & no impacts & $\begin{array}{l}\text { decreasing } \\
\text { revenues }\end{array}$ & $\begin{array}{l}\text { seriously } \\
\text { decreasing } \\
\text { revenues }\end{array}$ & $\begin{array}{l}\text { increasing } \\
\text { revenues }\end{array}$ & $\begin{array}{l}\text { seriously } \\
\text { increasing } \\
\text { revenues }\end{array}$ & \\
\hline \multirow{6}{*}{ 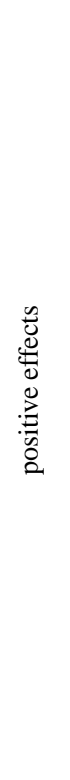 } & $\begin{array}{l}\text { origin of increasing } \\
\text { revenues }\end{array}$ & $\begin{array}{l}\text { public admin- } \\
\text { istration }\end{array}$ & $\begin{array}{l}\text { other } \\
\text { companies }\end{array}$ & $\begin{array}{l}\text { private } \\
\text { households }\end{array}$ & \multirow{3}{*}{$\begin{array}{l}\text { more orders } \\
\text { mitigation } \\
\text { measures } \\
\text { more } \\
\text { insurance com- } \\
\text { panies }\end{array}$} & \multirow{3}{*}{$\begin{array}{l}\text { higher demand } \\
\text { for producer } \\
\text { goods } \\
\text { higher demand } \\
\text { consumer } \\
\text { goods }\end{array}$} & \multirow{3}{*}{$\begin{array}{l}\text { higher demand } \\
\text { for other inputs } \\
\text { higher demand } \\
\text { wholesale }\end{array}$} \\
\hline & & $\begin{array}{l}\text { more orders } \\
\text { repair }\end{array}$ & $\begin{array}{l}\text { more orders } \\
\text { new construc- } \\
\text { tion }\end{array}$ & $\begin{array}{l}\text { more orders } \\
\text { clean-up }\end{array}$ & & & \\
\hline & $\begin{array}{l}\text { triggers of } \\
\text { increasing revenues }\end{array}$ & $\begin{array}{l}\text { more overnight } \\
\text { stays due to } \\
\text { disaster tourism }\end{array}$ & $\begin{array}{l}\text { more overnight } \\
\text { stays due to } \\
\text { loyalty with the } \\
\text { regions }\end{array}$ & $\begin{array}{l}\text { more granting } \\
\text { of credits }\end{array}$ & & & \\
\hline & $\begin{array}{l}\text { categories of } \\
\text { investments }\end{array}$ & $\begin{array}{l}\text { repairs of } \\
\text { structures and } \\
\text { infrastructures } \\
\text { risk } \\
\text { management }\end{array}$ & $\begin{array}{l}\text { new construc- } \\
\text { tion of buil- } \\
\text { dings } \\
\text { others }\end{array}$ & $\begin{array}{l}\text { expansion of } \\
\text { structures }\end{array}$ & $\begin{array}{l}\text { mitigation } \\
\text { measures }\end{array}$ & $\begin{array}{l}\text { adjustment of } \\
\text { production and } \\
\text { storage }\end{array}$ & $\begin{array}{l}\text { insurance com- } \\
\text { panies }\end{array}$ \\
\hline & $\begin{array}{l}\text { positive effects of } \\
\text { the event }\end{array}$ & open question & & & & & \\
\hline & $\begin{array}{l}\text { profiteers of the } \\
\text { event }\end{array}$ & open question & & & & & \\
\hline
\end{tabular}


Table A1. Continued.

\begin{tabular}{|c|c|c|c|c|c|c|c|}
\hline topic & question & attributes & & & & & \\
\hline \multirow{5}{*}{ 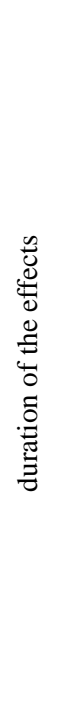 } & \multirow[t]{2}{*}{$\begin{array}{l}\text { duration of the } \\
\text { economic effects } \\
\text { on the company }\end{array}$} & $\begin{array}{l}\text { during the } \\
\text { event }\end{array}$ & $\begin{array}{l}\text { following } \\
\text { months (Sep- } \\
\text { tember to De- } \\
\text { cember 2005) }\end{array}$ & $\begin{array}{l}\text { winter season } \\
(2005 / 2006)\end{array}$ & $\begin{array}{l}\text { summer season } \\
(2006)\end{array}$ & until 2007 & until 2008 \\
\hline & & until 2009 & until 2010 & $\begin{array}{l}\text { until today } \\
\text { (2011) }\end{array}$ & & & \\
\hline & \multirow[t]{2}{*}{$\begin{array}{l}\text { duration of the } \\
\text { economic effects } \\
\text { on the region }\end{array}$} & $\begin{array}{l}\text { during the } \\
\text { event }\end{array}$ & $\begin{array}{l}\text { following } \\
\text { months (Sep- } \\
\text { tember to De- } \\
\text { cember 2005) }\end{array}$ & $\begin{array}{l}\text { winter season } \\
(2005 / 2006)\end{array}$ & $\begin{array}{l}\text { summer season } \\
(2006)\end{array}$ & until 2007 & until 2008 \\
\hline & & until 2009 & until 2010 & $\begin{array}{l}\text { until today } \\
\text { (2011) }\end{array}$ & & & \\
\hline & $\begin{array}{l}\text { annual change in } \\
\text { revenues in \% } \\
\text { (basis 2002, } 2003 \text { to } \\
2009 \text { ) }\end{array}$ & $\begin{array}{l}<-20 \\
1 \text { to } 5\end{array}$ & $\begin{array}{l}-20 \text { to }-16 \\
6 \text { to } 10\end{array}$ & $\begin{array}{l}-15 \text { to }-11 \\
11 \text { to } 15\end{array}$ & $\begin{array}{l}-10 \text { to }-6 \\
16 \text { to } 20\end{array}$ & $\begin{array}{l}-5 \text { to }-1 \\
>20\end{array}$ & 0 \\
\hline
\end{tabular}

Table A2. Main sample characteristics of quantitative variables.

\begin{tabular}{|c|c|c|c|c|c|c|}
\hline & $n$ & $\min$ & $\max$ & mean & median & std. dev. \\
\hline direct loss in $\%$ of annual revenue & 53 & 0.1 & 400 & 29.6 & 10 & 69.6 \\
\hline indirect loss in $\%$ of annual revenue (including business interruption) & 80 & 0.1 & 50 & 11.4 & 10 & 11.7 \\
\hline investments in $\%$ of annual revenue & 54 & 1 & 225 & 22.6 & 7.5 & 41.5 \\
\hline input region in $\%$ of total input & 159 & 0 & 100 & 47.3 & 50 & 38.2 \\
\hline input federal state in $\%$ of total input & 159 & 0 & 100 & 16.1 & 10 & 19.9 \\
\hline input Austria in $\%$ of total input & 160 & 0 & 100 & 20.3 & 10 & 26.5 \\
\hline input foreign countries in $\%$ of total input & 160 & 0 & 100 & 17.2 & 3,5 & 27.8 \\
\hline sales in the region in $\%$ of total sales & 170 & 0 & 100 & 58.9 & 70 & 39.8 \\
\hline sales federal state in $\%$ of total sales & 169 & 0 & 100 & 11.5 & 1,0 & 19 \\
\hline sales Austria in $\%$ of total sales & 169 & 0 & 80 & 6.3 & 0 & 13.7 \\
\hline sales foreign countries in $\%$ of total sales & 169 & 0 & 100 & 24.1 & 0 & 35.3 \\
\hline number of employee absences due to closed transport networks & 58 & 1 & 450 & 13.5 & 3 & 59 \\
\hline duration of employee absence due to closed transport networks & 56 & 1 & 60 & 6.9 & 5 & 9.2 \\
\hline number of employee absences due to emergency operations & 61 & 1 & 30 & 3.4 & 2 & 4.8 \\
\hline duration of employee absence due to emergency operations in days & 60 & 1 & 30 & 4.3 & 3 & 4.2 \\
\hline number of employee absences due to injuries & 12 & 1 & 10 & 2.7 & 2 & 2.6 \\
\hline duration of employee absence due to injuries in days & 11 & 1 & 90 & 15.6 & 4 & 27.1 \\
\hline
\end{tabular}


Table A3. Calculation of GDP/GRP in Euros per employee and working day and per economic sector based on the main data of the structural business statistics from Austria 2008 ÖNACE classification for private economic sectors ${ }^{1}$. Source: Statistics Austria and the authors' own calculations.

\begin{tabular}{|c|c|c|c|c|c|c|c|}
\hline ÖNACE 2008 classification Statistics Austria & $\begin{array}{l}\text { number of } \\
\text { companies }\end{array}$ & $\begin{array}{r}\text { total } \\
\text { employees }\end{array}$ & $\begin{array}{r}\text { total revenues } \\
\text { in Euros per } \\
\text { employee and } \\
\text { working day }{ }^{2}\end{array}$ & $\begin{array}{r}\text { gross added } \\
\text { value in factor } \\
\text { costs in } \\
, 000 \text { Euros }{ }^{3}\end{array}$ & $\begin{array}{r}\text { gross added } \\
\text { value in production } \\
\text { costs in } \\
\text { 000 Euros }{ }^{3}\end{array}$ & $\begin{array}{l}\text { GDP/GRP in } \\
\text { '000 Euros }\end{array}$ & $\begin{array}{l}\text { GDP/GRP pe } \\
\text { employee and } \\
\text { working day } \\
\text { in Euro }\end{array}$ \\
\hline mining & 357 & 6238 & 1353 & 950297 & 45490000 & 51691689 & 357 \\
\hline production of goods & 25319 & 606526 & 1002 & 41218361 & & & \\
\hline energy supply & 1569 & 28289 & 4210 & 5302926 & 8630000 & 9806535 & 899 \\
\hline water supply, disposal & 1929 & 17912 & 931 & 1585152 & & & \\
\hline construction & 29878 & 273655 & 614 & 14175564 & 17520000 & 19908516 & 308 \\
\hline retail, automobile repair and maintenance & 73038 & 612872 & 1393 & 26474320 & 32150000 & 36533036 & 253 \\
\hline transport and logistics & 13780 & 211567 & 688 & 12745268 & 11780000 & 13385977 & 268 \\
\hline accommodation and gastronomy & 44089 & 258901 & 237 & 6944125 & 12310000 & 13988232 & 229 \\
\hline information and communication & 15491 & 91076 & 849 & 7572186 & 8150000 & 9261096 & 431 \\
\hline banks and insurance companies & 6798 & 126597 & 2205 & 18222193 & 12070000 & 13715513 & 459 \\
\hline housing and real estate & 15791 & 41934 & 1374 & 7115312 & 45840000 & 52089405 & 519 \\
\hline engineering and professional services & 55977 & 202788 & 525 & 11407208 & & & \\
\hline other economic services & 12013 & 180248 & 419 & 8217396 & & & \\
\hline other services & 1455 & 4250 & 337 & 156061 & n.a. ${ }^{4}$ & n.a. ${ }^{4}$ & n.a. ${ }^{4}$ \\
\hline total/mean & 297484 & 2662853 & $1153^{5}$ & 162086369 & 193940000 & 220380000 & $414^{5}$ \\
\hline
\end{tabular}

${ }^{1}$ Without state activities, health and the social sector, and education, ${ }^{2}$ we assume that the average working year of one employee consists of 236 working days ( 365 days minus weekends and minus 25 days holiday), ${ }^{3}$ depending on the statistical source and desired result, different figures for gross added value are given: gross added value in factor costs = gross added value in production costs - other net production charges (e.g. import taxes, subventions), ${ }^{4}$ due to statistical conventions, gross added value in production costs of other services is not available, ${ }^{5}$ arithmetic mean.

Acknowledgements. This paper was presented at the EGU General Assembly 2012, Session Costs of Natural Hazards, Geophysical Research Abstracts Vol. 14, EGU2012-1869, 2012. The research was supported by the Austrian Academy of Sciences (ÖAW) as part of the "Alpenforschung" national research funding programme. The "INNrisk, Risk Factor Inn - transdisciplinary analysis of the 2005 flood in the Federal State of Tyrol, Austria" project primarily aimed to improve public risk management and decision support by estimating the economic consequences of the floods of 2005. Moreover, the EU-funded FP7 "ConHaz - Costs of Natural Hazards" (http://conhaz.org) project and especially the outcome of the "Alpine Hazards" work package serve as the basis for this research. We thank various departments of the federal state government of Tyrol for providing spatial and loss data. We are grateful to B. Scott for language proofing and A. Brucker for supporting data analysis. We also want to express our gratitude to B. Jongman and two anonymous reviewers for contributing critiques and detailed recommendations, which helped to improve an earlier version of the paper.

Edited by: H. Kreibich

Reviewed by: B. Jongman and two anonymous referees

\section{References}

Benson, C. and Clay, E. J.: Understanding the Economic and Financial Impacts of Natural Disasters, Disaster Risk Management Series No. 4, The International Bank for Reconstruction and Development/The World Bank, 2004.

BMLFUW: Federal Ministry of Agriculture, Forestry, Environment and Water Management: Richtlinien für die Wirtschaftlichkeitsuntersuchung und Priorisierung von Maßnahmen der Wildbach und Lawinenverbauung gemäß $\S 3$ Abs. 2 Z 3 Wasserbautenförderungsgesetz 1985, Vienna, 2008a.

BMLFUW: Federal Ministry of Agriculture, Forestry, Environment and Water Management: Kosten-Nutzen-Untersuchungen im Schutzwasserbau Richtlinie, KNU gemäß §3 Abs. 2 Ziffer 3, Wasserbautenförderungsgesetz, Vienna, 2008b.

Bubeck, P. and Kreibich, H.: Natural Hazards: Direct costs and losses due to the disruption of production processes, final report, http://conhaz.org/project/cost-assessment-work-packages/ wp1-8-final-reports/CONHAZ\%20REPORT\%20WP01_2.pdf/ view (last access: 29 January 2014), 2011.

Cavallo, E. and Noy, I.: The Economics of Natural Disasters - A Survey, Inter- American Development Bank, IDB Working paper Series, IDB-WP-123, 2009.

Chatterton, J., Viavattene, C., Morris, J., Penning-Rowsell, E., and Tapsell, S.: The costs of the summer 2007 floods in England, Environmental Agency, Bristol, 2010.

Cochrane, H. C.: Economic loss: myth and measurement, Disaster Prevention and Management, 13, 290-296, doi:10.1108/09653560410556500, 2004.

Commission of the European Communities: European Union Solidarity Fund Annual report 2006, Brussels, 2007.

Central Auditing Authority of the Federal State of Tyrol: Rechnungsabschluss 2005 des Landes Tirol, www.tirol.gv. at/fileadmin/www.tirol.gv.at/landtag/landesrechnungshof/ downloads/ber_2006/e2006rechnungsabschluss05internet.pdf (last access: 17.04. 2013), 2006 (in German).

Central Auditing Authority of the Federal State of Tyrol: Rechnungsabschluss 2006 des Landes Tirol, www.tirol.gv. at/fileadmin/www.tirol.gv.at/landtag/landesrechnungshof/ downloads/ber_2007/e2007ra2006_01.pdf (last access: 17.04. 2013), 2007 (in German). 
Department of Natural Resources and Mines: Guidance on the assessment of tangible flood damages, Queensland, 2002.

Eurostat: European system of accounts ESA 1995, available at http://circa.europa.eu/irc/dsis/nfaccount/info/data/esa95/ en/titelen.htm., (last access: 25 July 2012), 2012.

Federal Emergency Management Agency (FEMA): Multi-hazard Loss Estimation Methodology - Flood Model, HAZUS ${ }^{\circledR}$ MH MR5, Technical Manual, Washington, DC, 2011.

Federal State of Tyrol: Hydrologische Übersicht Jahr 2005, www.tirol.gv.at/uploads/media/hueb0805.pdf (last access: 2 May 2013), 2006 (in German).

Gruber, M.: Alternative solutions for public and private catastrophe funding in Austria, Nat. Hazards Earth Syst. Sci., 8, 603-616, doi:10.5194/nhess-8-603-2008, 2008.

Hallegatte, S., Hourcade, J.-C., and Dumas, P.: Why economic dynamics matter in assessing climate change damages: illustration on extreme events, Ecol. Econ., 62, 330-340, 2007.

Hallegatte, S.: An adaptive regional input-output model and its application to the assessment of the economic cost of Katrina, Risk Analysis, 28, 779-799, 2008.

Hallegatte, S. and Dumas, P.: Can natural disasters have positive consequences?, Investigating the role of embodied technical change, Ecol. Econ., 68, 777-786, 2008.

Hallegatte, S. and Przyluski, V.: The Economics of Natural Disasters - Concepts and Methods, policy research working paper 5507, The World Bank, 2010.

Hallegatte, S., Ranger, N., Mestre, O., Dumas, P., Corfee-Morlot, J., Herweijer, C., and Wood, R. M.: Assessing climate change impacts, sea level rise and storm surge risk in port cities: a case study on Copenhagen, Climatic Change, 104, 113-137, doi:10.1007/s10584-010-9978-3, 2011.

Holub, M. and Fuchs, S.: Mitigating mountain hazards in Austria - legislation, risk transfer, and awareness building, Nat. Hazards Earth Syst. Sci., 9, 523-537, doi:10.5194/nhess-9-5232009, 2009.

Kletzan, D., Köppl, A. Kratena, K., and Wegscheider, A.: Analyse der Hochwasserereignisse vom August 2002 -FloodRisk WP Ökonomische Aspekte TP 02, StartClim.10, Ökonomische Aspekte des Hochwassers 2002: Datenanalyse, Vermögensrechnung und gesamtwirtschaftliche Effekte, Vienna, 2004 (in German).

Kratena, K. and Zakarias, G.: MULTIMAC IV: A Disaggregated Econometric Model of the Austrian Economy, WIFO Working Papers, No. 160, Vienna, 2001.

Leiter, A., Oberhofer, M. H., and Raschky, P. A.: Creative Disasters? Flooding Effects on Capital, Labour and Productivity within European Firms, Environmental and Resource Economics, 43, 333 $350,2009$.

Lin, H. C., Kuo, Y. L., Shaw, D., Chang, M. C., and Kao, T. M.: Regional-economic impact analysis of earthquakes in northern Taiwan and its implications for disaster reduction policies, Nat. Hazards, 61, 603-620, doi:10.1007/s11069-011-0049-5, 2012.

Loayza, N., Olaberría, E., Rigolini, J., and Christiansen, L.: Natural Disasters and Growth-Going Beyond the Averages, World Bank Policy Research Working Paper 4980, Washington, DC, United States, The World Bank, 2009.

Merz, B., Kreibich, H., Schwarze, R., and Thieken, A.: Review article "Assessment of economic flood damage", Nat. Hazards
Earth Syst. Sci., 10, 1697-1724, doi:10.5194/nhess-10-16972010, 2010.

Messner, F., Penning-Rowsell, E., Green, C., Meyer, V., Tunstall, S., van der Veen, A, Tapsell, S., Wilson, T., Krywkow, J., Logtmeijer, C., Fernández-Bilbao, A., Geurts, P., Haase, D., and Parker, D.: Evaluating flood damages: guidance and recommendations on principles and methods, FLOODsite Project Deliverable D9.1, 2007.

Meyer, V., Becker, N., Markantonis, V., Schwarze, R., van den Bergh, J. C. J. M., Bouwer, L. M., Bubeck, P., Ciavola, P., Genovese, E., Green, C., Hallegatte, S., Kreibich, H., Lequeux, Q., Logar, I., Papyrakis, E., Pfurtscheller, C., Poussin, J., Przyluski, V., Thieken, A. H., and Viavattene, C.: Review article: Assessing the costs of natural hazards - state of the art and knowledge gaps, Nat. Hazards Earth Syst. Sci., 13, 1351-1373, doi:10.5194/nhess-13-1351-2013, 2013.

MURL: Potentielle Hochwasserschäden am Rhein in NordrheinWestfalen, Ministerium für Umwelt, Raumordnung und Landwirtschaft des Landes Nordrhein-Westfalen, 2000 (in German).

National Research Council (NRC): The Impacts of Natural Disasters: A Framework for Loss Estimation, Committee on Assessing the Costs of Natural Disasters National Academy Press, Washington, DC, 80 pp., 1999.

Nöthiger, C.: Naturgefahren und Tourismus in den Alpen - untersucht am Lawinenwinter 1999 in der Schweiz, SLF, Davos, 2003 (in German).

Nöthiger, C. and Elsasser, H.: Natural Hazards and Tourism: New Findings on the European Alps, Mt. Res. Dev., 24, 24-27, 2004.

Pfurtscheller, C., Lochner, B., and Thieken, A. H.: Costs of Alpine Hazards, final report, available at http://conhaz.org/ project/cost-assessment-work-packages/wp1-8-final-reports/ CONHAZ\%20REPORT\%20WP08_1.pdf/view (last access: 29 January 2014), Innsbruck, 2011.

Pfurtscheller, C. and Thieken, A. H.: The price of safety: costs for mitigating and coping with Alpine hazards, Nat. Hazards Earth Syst. Sci., 13, 2619-2637, doi:10.5194/nhess-13-26192013, 2013.

Przyluski, V. and Hallegatte, S.: Indirect Costs of Natural Hazards, final report, available at http://conhaz.org/ project/cost-assessment-work-packages/wp1-8-final-reports/ CONHAZ\%20REPORT\%20WP02_2.pdf/view (last access: 29 January 2014), 2011.

Ranger, N., Hallegatte, S., Bhattacharya, S., Bachu, M., Priya, S., Dhore, K., Rafique, F., Mathur, P., Naville, N., Henriet, F., Herweijer, C., Pohit, S., and Corfee-Morlot, J.: An assessment of the potential impact of climate change on flood risk in Mumbai, Climatic Change, 104, 139-167. doi:10.1007/s10584-010-9979-2, 2011.

Rose, A.: Economic Principles, Issues, and Research Priorities in Natural Hazard Loss Estimation, edited by: Okuyama, Y. and Chang, S.: Modeling the Spatial Economic Impacts of Natural Hazards, Springer, Heidelberg, 13-36, 2004.

Rose, A. and Liao, S.: Modeling regional-economic resilience to disasters: a computable general equilibrium analysis of water service disruptions, J. R. Sci., 45, 75-112, 2005.

Scawthorn, C., Blais, N., Seligson, H., Tate, E., Mifflin, E., Thomas, W., Murphy, J., and Jones, C.: HAZUS-MH Flood Loss Estimation Methodology. I: Overview and Flood Hazard Character- 
ization, Nat. Hazard Rev., 7, 60-71, doi:10.1061/(ASCE)15276988(2006)7:2(60), 2006a.

Scawthorn, C., Flores, P., Blais, N., Seligson, H., Tate, Chang, S., E., Mifflin, E., Thomas, W., Murphy, J., Jones, C., and Lawrence, M.: HAZUS-MH Flood Loss Estimation Methodology, II. Damage and Loss Assessment, Nat. Hazard Rev., 7, 7281, doi:10.1061/(ASCE)1527-6988(2006)7:2(72), 2006b.

Schwarze, R.: Indirekte regionalwirtschaftliche und makroökonomische Schäden, edited by: Thieken, A. H., Seifert, I., and Merz, B., Hochwasserschäden - Erfassung, Abschätzung und Vermeidung, München, 217-222, 2011 (in German).

Sinabell, F. and Streicher, G.: Wirtschaftliche Bewertung von Hochwässern, in: Hochwässer: Bemessung, Risikoanalyse und Vorhersage, Wiener Mitteilungen Band 216, Vienna, 165-174, 2009 (in German).
Sinabell, F., Fritz, O., Puwein, W., Streicher, G., and Weinberger, D.: Eine volkswirtschaftliche Analyse der Wildbach und Lawinenverbauung, Austrian Institute of Economic Research WIFO, Vienna 2009 (in German).

SLF: Der Lawinenwinter 1999 - Ereignisanalyse, WSL Institute for Snow and Avalanche Research SLF, Davos, 2000.

Statistics Austria: Standard-Dokumentation Metainformationen Volkswirtschaftliche Gesamtrechnung, VGR - Jahresrechnung, Vienna, 2010 (in German).

Statistics Austria: Standard-Dokumentation Metainformationen zur Leistungs- und Strukturstatistik im Produzierenden und Dienstleistungsbereich, Vienna, 2011 (in German).

Thieken, A. H., Cammerer, H., and Pfurtscheller, C.: Risk Management, Adaptation, and Monetary Aspects, edited by: Lamond, J., Booth, C., Hammond, F., and Proverbs, D.: Flood Hazards, Impacts and Responses for the Built Environment, CRC Press, Boca Raton, 177-190, 2012. 